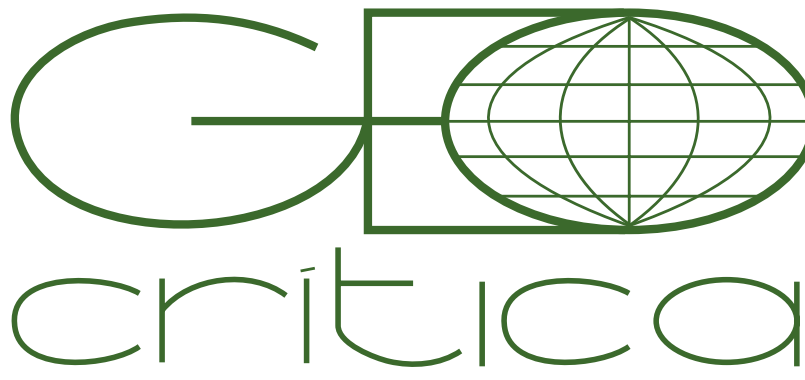

\section{Scripta Nova}

Revista Electrónica de Geografía y Ciencias Sociales Universitat de Barcelona

1 de junio de 2017

\title{
LA ECONOMÍA POLÍTICA DE LA ESCLAVITUD: LOS ARGUMENTOS ECONÓMICOS DEL DEBATE ABOLICIONISTA ESPAÑOL DEL SIGLO XIX
}

\author{
Luis Perdices de Blas \\ José Luis Ramos Gorostiza \\ Dpto. Historia e Instituciones Económicas I \\ Ftad. Ciencias Económicas y Empresariales \\ Campus de Somosaguas, Universidad Complutense \\ Recibido:20/06/2016; Aceptado:21/12/2016
}

\section{La economía política de la esclavitud: los argumentos económicos del debate abolicionista español del siglo XIX (Resumen)}

La abolición de la esclavitud en las colonias españolas del Caribe fue un largo y tortuoso proceso que no se completó plenamente hasta 1886. En el debate abolicionista español se dieron cita argumentos de muy diversa índole: morales, religiosos, jurídicos, humanitarios, políticos y económicos. Estos últimos no han recibido hasta ahora atención específica por parte de los historiadores, que sin embargo sí se han interesado por otros muchos aspectos del proceso abolicionista. Este trabajo se centra en analizar los principales argumentos económicos esgrimidos a lo largo del siglo XIX tanto por los esclavistas como por los abolicionistas españoles, viendo cuáles fueron sus referentes intelectuales en el ámbito europeo.

Palabras clave: esclavitud, España, siglo XIX, debate abolicionista, argumentos económicos

The political economy of slavery: the economic arguments of the Spanish nineteenth century abolitionist debate (Abstract)

The abolition of slavery in the Spanish Caribbean colonies was a long and tortuous process that was not fully completed until 1886. In the Spanish abolitionist debate arguments of various kinds were used: moral, religious, legal, humanitarian, political and economic. These latter have so far not received specific attention from historians, who have been interested however in many other aspects of the abolitionist process. This work focuses on the main economic arguments used by pro-slavery and abolitionist Spanish authors during the nineteenth century, analyzing their European intellectual sources.

Key words: slavery, Spain, 19th century, abolitionist debate, economic arguments 
La abolición de la esclavitud en las colonias españolas del Caribe fue un largo y tortuoso proceso que no se completó plenamente hasta 1886, con la abolición definitiva en Cuba. El debate abolicionista español se desarrolló en varias fases a través de distintos medios (escritos dirigidos al poder político, estudios monográficos, artículos de prensa, discursos en las Cortes, conferencias, proyectos extraoficiales, etc.) y en él se dieron cita argumentos de muy diversa índole: morales, religiosos, jurídicos, humanitarios, políticos y económicos. Estos últimos no han recibido hasta ahora atención específica por parte de los historiadores, que sin embargo sí se han interesado por otros muchos aspectos del proceso abolicionista español del XIX (asociaciones, principales figuras públicas, iniciativas legislativas, condicionantes políticos, etc.). Por eso, este trabajo se centra en analizar los principales argumentos económicos esgrimidos a lo largo de la centuria tanto por los esclavistas como por los abolicionistas españoles, viendo cuáles fueron sus referentes intelectuales en el ámbito europeo.

Evidentemente, examinar la esclavitud desde un punto de vista estrictamente económico equivale a discutir aspectos tales como su coste relativo frente al trabajo libre, su eficiencia, su impacto en el modelo productivo, la innovación y las posibilidades de especialización, o su posible relación con políticas comerciales concretas. Pues bien, el análisis económico de la esclavitud se inició en la segunda mitad del siglo XVIII, y Adam Smith estableció el que iba a ser el eje central en torno al que giraría luego el debate europeo (Say, McCulloch, Carlyle, etc.): la mano de obra esclava era en general más cara y menos productiva que la libre, pero podía ser claramente rentable en las economías antillanas dedicadas al azúcar y el tabaco. En el caso español, esto último fue precisamente lo que marcó el punto central de discusión: ¿Era realmente Cuba una excepción en virtud de sus peculiares características? ¿Qué enseñanzas económicas cabía derivar de lo que había supuesto la emancipación de los esclavos en otras islas caribeñas?

Es importante matizar que el presente trabajo se circunscribe al ámbito de la historia de las ideas: examina los argumentos económicos a favor y en contra de la esclavitud utilizados en la España del siglo XIX, pero no pretende en ningún caso contrastarlos con lo que hoy señalan los estudios de historia económica sobre la rentabilidad de la esclavitud, en la línea del famoso libro de Fogel y Engerman Tiempo en la cruz-referido al sur de Estados Unidos. Ello sobrepasaría con mucho la limitada extensión de un ensayo académico.

El artículo se estructura del siguiente modo. En primer lugar se pasa revista a lo que fue el análisis económico de la esclavitud en Europa desde mediados del siglo XVIII hasta el último tercio del siglo XIX, con el final de la Escuela Clásica. Luego se establecen las tres etapas del debate abolicionista español siguiendo la periodificación que realizara en su día el economista decimonónico Gabriel Rodríguez. A continuación se analizan con detenimiento los principales argumentos 
económicos empleados por esclavistas y abolicionistas en cada una de dichas etapas, prestando atención a sus posibles fuentes intelectuales. Para terminar, el trabajo se cierra con un apartado dedicado a conclusiones.

\section{El análisis económico de la esclavitud en Europa desde mediados del siglo XVIII}

La esclavitud fue un tema marginal para los economistas de los siglos XVIII y XIX. Además de ocuparse poco de ella, en la mayoría de los casos lo hicieron sin conocer directamente la realidad económica de las plantaciones, es decir, sin haber estado nunca en las zonas esclavistas del Caribe, Brasil o el sur del Estados Unidos. En cualquier caso, lo cierto es que hasta la segunda mitad del siglo XVIII la esclavitud no fue analizada desde una perspectiva económica, tal vez porque se consideraba que ello no valía la pena: el sentido común parecía sugerir que -dadas las hondas raíces históricas de dicha institución y lo lucrativo del tráfico negrero-debía tratarse, en todo caso, de una opción productiva evidentemente beneficiosa para quien la adoptaba. Sin embargo, desde finales de la década de 1750 algunos mercantilistas como James Steuart (1713-1780), o fisiócratas como el Marqués de Mirabeau (17151789) y Pierre-Paul Le Mercier de la Rivière (1719-1801), se atrevieron a poner en cuestión, de forma pionera, tal afirmación ${ }^{1}$.

Pero fue Pierre Samuel Du Pont de Nemours (1739-1817) quien más explícitamente abordó el tema de la esclavitud desde una perspectiva económica. En un largo artículo aparecido en la revista fisiócrata Efemérides del Ciudadano, de la que era editor, Du Pont intentó calcular con datos reales y estimaciones propias el coste del trabajo esclavo en las plantaciones de caña y compararlo con el del trabajo libre. Su conclusión fue que éste último era claramente más barato. Para realizar el cálculo del coste medio anual del trabajo esclavo tuvo en cuenta cosas tales como la temprana mortalidad de los esclavos, las pérdidas por fugas, los gastos en vigilancia y en sofocar revueltas, o la mala preparación de las cosechas y las herramientas malogradas por la ignorancia o mala voluntad de los esclavos, todo ello dentro de un clima de absoluta falta de estímulo natural a la producción ${ }^{2}$.

Pero aunque Du Pont consideró que con su "aritmética política" había probado la falta de sentido económico de la esclavitud -reforzando así el juicio condenatorio de la filosofía hacia esa institución "abominable"-, no convenció a economistas como Anne-Robert-Jacques Turgot (1727-1781), que en su intercambio epistolar con Du Pont siguió manteniendo justamente lo contrario: pese a ser una institución bárbara e injusta que no era buena para la sociedad en su conjunto, sí podía resultar rentable para los propietarios individuales; es decir, cualquiera que en las islas caribeñas empleara trabajo esclavo lo encontraría beneficioso, aunque quizá no tanto como tradicionalmente se había pensado ${ }^{3}$. La abundancia de tierra y la

1 Groenewegen 2001, p. 84-5; Steiner 2003, p. 135-6.

2 Du Pont 1771.

3 Steiner 2003, p. 136-7. 
escasez de mano de obra explicaban la prevalencia de la esclavitud en las colonias de América, y en todo caso era preciso un continuo y muy abundante tráfico desde África con el fin de mantener el número necesario de esclavos para los cultivos, pues el maltrato y los trabajos excesivos causaban una gran mortalidad entre ellos ${ }^{4}$.

Todos los miembros de la escuela clásica de economía política que arrancó con Adam Smith condenaron la esclavitud desde un punto de vista moral, y algunos como Thornton- fueron asimismo activos miembros del movimiento abolicionista. En general también tendieron a cuestionar de un modo u otro la esclavitud por motivos económicos, aunque con diferencias en los argumentos utilizados.

Smith (1723-1790) consideraba la esclavitud como la más triste situación en la que podía verse un ser humano: los esclavos llevaban una vida miserable e infeliz completamente a merced de otros 5 . Pero además, la esclavitud no tenía sentido desde el punto de vista económico: un esclavo era más caro y también menos productivo que un trabajador libre, pues el esclavo no tenía incentivo alguno a esforzarse más allá de lo estrictamente necesario para la mera subsistencia:

La experiencia de todas las épocas y naciones demuestra que el trabajo ejecutado por esclavos es el más caro de todos, aunque aparentemente sólo cueste el sustento. Una persona que no puede adquirir propiedades sólo está interesada en comer todo lo que pueda y trabajar lo menos posible. Cualquier trabajo que efectúe más allá de lo necesario para su propio sustento sólo se le puede imponer mediante la violencia, jamás lo hará voluntariamente ${ }^{6}$

Asimismo, el trabajo esclavo tampoco favorecía la innovación tecnológica:

Los esclavos raramente tienen inventiva, por lo que las innovaciones más importantes, tanto en maquinaria como en la organización y distribución del trabajo para facilitar o reducir las tareas, fueron descubrimientos de hombres libres. Si un esclavo propusiera una mejora de este tipo, su amo probablemente la consideraría como una sugerencia debida a la pereza ${ }^{7}$.

Pero ahí no terminaban los problemas. Por un lado, también podía derivarse de la argumentación de Smith -aunque él no lo afirmase explícitamente-que la esclavitud constituía un obstáculo importante a la libre especialización funcional o división del trabajo social (que para el escocés constituía la auténtica palanca de la riqueza). Por otro lado, la poderosa motivación del propio interés sólo contribuía efectivamente al bienestar general bajo determinados arreglos institucionales, y en este sentido las Lecciones de jurisprudencia (1762-3) parecen transmitir claramente la idea de que el funcionamiento beneficioso de la "mano invisible" -a la que luego aludiría Smith en La Riqueza de las Naciones y la Teoría de los sentimientos moralesse refería a sociedades de intercambio no basadas en la institución de la esclavitud,

\footnotetext{
4 Turgot 1998, p. 100

5 Smith 1982, p. 178.

6 Smith 1987, p. 440.

7 Smith 1987, p. 719.
} 
pues únicamente en tales sociedades el consumo de los ricos podía redundar en beneficio de toda la sociedad ${ }^{8}$.

Pero, pese a tantos y tan importantes inconvenientes, lo cierto era que la esclavitud estaba en el origen de todas las sociedades y había persistido a lo largo del tiempo, y Smith lo explicaba -como ya había apuntado en sus Lecciones $^{9}$ - por el deseo natural del hombre de imponer su dominio sobre los demás ${ }^{10}$. En la práctica, sin embargo, sólo el cultivo del azúcar y el tabaco eran realmente compatibles con el trabajo esclavo gracias a los grandes beneficios que proporcionaban estas actividades:

Los beneficios de las plantaciones de azúcar en cualquiera de las colonias inglesas en las Indias Occidentales son, generalmente, mayores que las de cualquier otra clase de cultivo conocido en América o Europa, y las ganancias de las plantaciones de tabaco, aunque inferiores a los de las plantaciones de azúcar, son muy superiores [...] a las del cultivo del grano. Ambas se pueden permitir la utilización de esclavos, pero las de azúcar con mayor ventaja que las de tabaco $^{11}$.

El análisis de Smith sobre la esclavitud resultó muy influyente en el siglo XIX, pero tuvo ya un importante impacto desde el principio dentro de la ilustración escocesa: por ejemplo, en las Observaciones acerca de la distinción de rangos en la sociedad ( 1771 ) de John Millar, o en Observaciones sobre la esclavitud (1789) de James Anderson.

No obstante, los planteamientos smithianos sobre la esclavitud no fueron fácilmente aceptados por su gran seguidor continental, el francés Jean Baptiste Say (1767-1832). De hecho, Say mantuvo dos posturas bien diferenciadas a lo largo de su vida. Inicialmente, su posición fue completamente contraria a la de su admirado Smith. Así, en la primera edición de su Tratado de economía política (1803) -aparecida en plena rebelión de los esclavos en Haití (1791-1804), tras la primera abolición de la esclavitud en Francia en 1794, y justo después de su restablecimiento por Napoleón en 1802-, realizó una serie de cálculos sobre el coste del trabajo esclavo en las colonias concluyendo que era claramente más barato que el libre, y que además los esclavos podían ser incluso más productivos si estaban bien dirigidos. Frente a la idea de la baja productividad del esclavo debida a la ausencia de la motivación del propio interés (que habían defendido Smith y Du Pont), Say argumentó que la plantación no requería una mano de obra cualificada sino una buena supervisión, y que lo que contaba era el propio interés de los hacendados, que les llevaría a hacer el mejor uso posible de sus esclavos y a no sobrecargarles de trabajo para no reducir sus capacidades; por otra parte, si los hacendados defendían la esclavitud era precisamente porque sin duda la veían ventajosa en la práctica en términos económicos. Pero todo ello no significaba que la institución fuese conveniente: era

8 Pack 1996, p. 254, 259-60. Smith 1982, p. 194-6.

9 Smith 1982, p. 452.

10 Smith 1987, p. 440-1.

11 Smith 1987, p. 441. 
odiosa e inmoral y su abolición, aunque negativa para los hacendados, no lo sería para la sociedad en su conjunto. El azúcar podría producirse en Egipto o incluso en el sur de Europa y no costaría más (pues el ahorro derivado de no pagar un sueldo a los esclavos beneficiaba sólo al hacendado, no a los consumidores); por otra parte, las islas caribeñas pasarían a ser simples colonias de asentamiento para bien de la metrópoli y de los antiguos esclavos ${ }^{12}$.

Poco a poco, sin embargo, Say se fue mostrando cada vez menos convencido de las ventajas económicas de la esclavitud. En la segunda edición de su Tratado (1814) se distanció algo de los cálculos aparecidos en la primera edición de 1803, y en la quinta (1826) cambió por completo su postura. No pensaba ya que el trabajo esclavo fuese más productivo que el libre (aunque seguía manteniendo que era menos costoso) ni que el sistema esclavista de plantación de las Antillas resultara realmente favorable, pues degradaba las cualidades de la verdadera industria inteligencia, actividad y economía- y otros países podían ofrecer a Europa un azúcar más barato que el que proporcionaban Martinica y Guadalupe ${ }^{13}$. Finalmente, en su Curso completo de economía política práctica (1828-9), todavía bastantes años antes de que la esclavitud quedase definitivamente abolida en las colonias francesas en 1848, Say se situó ya claramente en la línea de Smith y Du Pont al subrayar también que los costes de mantenimiento del trabajo esclavo eran elevados y recaían en los dueños de las plantaciones; además -añadía- sin el apoyo y la protección de la metrópoli la aparente prosperidad de las colonias azucareras francesas nunca hubiera sido tal ${ }^{14}$.

Parece que uno de los que más pudo influir en este último posicionamiento de Say fue su yerno y discípulo Charles Comte (1782-1837), que había dedicado a la esclavitud el cuarto tomo de su Tratado de Legislación (1827) ${ }^{15}$. Para Comte, miembro destacado de la escuela liberal francesa, la existencia de violencia o coacción en las relaciones económicas que implicaba la esclavitud hacía que la comparación entre trabajo esclavo y libre quedase desvirtuada. En cualquier caso, se pronunció nítidamente a favor del trabajo libre por tres razones principales: los terribles efectos de la esclavitud en las facultades humanas que contribuían a la producción (pues los esclavos no derivaban ningún provecho de su trabajo, mientras la actitud de los amos se veía maleada por la propia disposición de esclavos); algunos indicadores de ineficiencia del sistema esclavista (como el hecho de que el noventa por ciento de los hacendados estuviese endeudado y a merced de sus acreedores, o que los estados esclavistas del sur de Estados Unidos pareciesen incapaces de desarrollar manufacturas propias y se vieran obligados a importar estos productos); y la inadecuada distribución de la riqueza en las áreas esclavistas -

12 Steiner 2003, p. 138. Say 1803, I, p. 218, 223-4, 226.

13 Steiner 2003, p. 139. Say 1839[1826], p. 192-6.

14 Steiner 2003, p. 140.

15 También pudo influir en Say el alemán Heinrich von Storch (1766-1835) y su Curso de economía política (1815): Hummel 2012, p. 33. 
completamente contraria a la moral y la justicia- que hacía que todo se consumiera allí improductivamente y nada se acumulase ${ }^{16}$.

Volviendo a las Islas Británicas, durante el primer tercio del siglo XIX los grandes autores clásicos - como Thomas Robert Malthus, David Ricardo o James Mill- no se interesaron por la cuestión de la esclavitud. Sin embargo, sí lo hicieron otros miembros menos destacados de la escuela, como John Rooke (1780-1856), Samuel Bailey (1791-1870), o Mountifort Longfield (1802-1884). Todos ellos -al igual que el filósofo utilitarista Jemery Bentham (1748-1832)- se pronunciaron inequívocamente en la línea smithiana de considerar el trabajo esclavo menos productivo por cuestión de incentivos. Sin embargo, Longfield no creía que el trabajo libre fuese siempre más barato que el esclavo, mientras que para Bailey lo verdaderamente relevante -al margen de la controversia en torno a si resultaba o no más barato- era que el trabajo libre era más eficiente y favorecía en mayor medida la prosperidad nacional ${ }^{17}$. Sí asumió en cambio plenamente la crítica smithiana a la esclavitud Harriet Martineau (1802-1876), la gran divulgadora de los principios de la economía clásica a través de novelas económicas, que viajó en 1834-6 a Estados Unidos, conoció de primera mano la realidad esclavista, y se convirtió en una activa abolicionista.

La siguiente figura en la que vale la pena detenerse es Edward Gibbon Wakefield (1796-1862), pues fue un autor destacado en cuestiones coloniales dentro del marco conceptual de la escuela clásica e introdujo dos matizaciones importantes respecto a la visión smithiana. Por un lado, en su Carta desde Sidney (1829) criticó a Smith por haber omitido el papel decisivo de los esclavos al referirse al establecimiento de las antiguas colonias griegas en el Mediterráneo; en esta misma línea, si bien mostró su desagrado hacia la esclavitud en América, admitió que dicha institución había contribuido mucho al desarrollo agrícola en las nuevas colonias donde existía una gran cantidad de tierra disponible por explotar y una gran desproporción entre oferta y demanda de mano de obra. Por ello, consideró que la "anti-cristiana" esclavitud era una especie de mal necesario: unos pocos miles de esclavos africanos podían hacer mucho por el desarrollo económico de Nueva Gales del Sur en Australia ${ }^{18}$. Más tarde, en su comparación de Europa y América (1833), afirmó ya abiertamente que en las zonas de nueva colonización la esclavitud era tanto rentable como eficiente, algo que reiteraría luego Herman Merivale (1806-1874) en sus Lecciones sobre colonización y colonias ( 1841 ) para todos aquellos casos en que la tierra fuese relativamente abundante y la mano de obra libre muy escasa. No obstante, Wakefield intentaría acercarse de nuevo a la postura smithiana en su libro Una visión del arte de la colonización (1849): en él subrayó que, si bien los altos ratios tierra-trabajo

16 Steiner 2003, p. 139-40. La visión anti-esclavista de Charles Comte tendría luego una influencia directa en los reformistas de la Cuba española: Ghorbal 2014.

17 Véase Hummel 2012, p. 35-6.

18 Groenewegen 2001, p. 85-6. 
hacían que la mano de obra esclava resultara "artificialmente" más barata, esta era en general más costosa que la libre y siempre mucho menos productiva ${ }^{19}$.

Por otra parte, Wakefield puso en cuestión otra idea apuntada por Smith y explicitada más tarde por Richard Whately (1787-1863), a saber: el rasgo diferencial común de la humanidad frente al resto de los animales era la capacidad para negociar y comerciar haciendo uso del lenguaje, lo que a su vez daba sentido a la especialización funcional. Frente a esta visión del intercambio como prueba de la común humanidad, Wakefield señaló en su edición de La Riqueza de 1835 que había razas -como los aborígenes australianos- que prácticamente no comerciaban y por tanto estaban más cerca del resto de los animales que de los humanos; por otra parte, el hecho de que los animales inferiores no comerciasen no se explicaba tanto porque fueran incapaces de usar el lenguaje, sino sobre todo porque no tenían razón para ello: sus deseos se restringían a comida y cobijo, mientras que los deseos humanos eran ilimitados ${ }^{20}$.

Como Wakefield, el economista escocés John Ramsay McCulloch (1789-1864) hizo asimismo una puntualización importante a la visión de Smith. En concreto, expresó sus opiniones económicas sobre la esclavitud en algunas páginas de la cuarta edición de 1849 de sus Principios de economía política (1825), cuando ya hacía tiempo que esta había sido oficialmente abolida en Gran Bretaña y sus colonias (1833). McCulloch señaló que si bien la experiencia mostraba que el trabajo libre tendía a ser normalmente más barato y eficiente que el trabajo esclavo, no ocurría así en las plantaciones azucareras de las Indias Occidentales, donde el clima resultaba totalmente inadecuado para la mano de obra europea. Además, a los africanos -que sí estaban adaptados a dicho clima- sólo se les podía hacer trabajar en las durísimas plantaciones de azúcar si eran esclavizados, dado que sus deseos eran limitados y que la satisfacción de sus necesidades básicas era barata y fácil en dichas zonas caribeñas $^{21}$. La mejor prueba de esta afirmación -como señalaba McCulloch en la nota XXIII de su edición de La Riqueza- era que, mientras los territorios españoles y portugueses de Cuba y Brasil seguían produciendo azúcar de forma rentable con trabajo esclavo, la producción azucarera de las colonias caribeñas británicas y francesas -donde la esclavitud había sido abolida- se había desplomado ${ }^{22}$. En definitiva, la rentabilidad y la eficiencia del trabajo libre y del esclavo dependían en gran medida de las circunstancias; por tanto, no cabía hacer afirmaciones universales al respecto como las formuladas por Du Pont y Smith.

También se ocupó de la esclavitud el gran John Stuart Mill ( 1806-1873), y lo hizo en dos ocasiones. La primera fue en el capítulo 5 (libro II) de sus Principios de economía política ( 1848). Al margen de congratularse de la abolición de tan cruel institución en las Indias Occidentales británicas (y posteriormente en otros lugares) ${ }^{23}$, Mill se situó

19 Hummel 2012, p. 38-40.

20 Levy y Peart 2001, p. 4.

21 Hummel 2012, p. 37.

22 Groenewegen 2001, p. 86.

23 Mill 1985, p. 236. 
en la línea smithiana de considerar en general menos productiva y relativamente más cara la mano de obra esclava que el trabajo libre, y además juzgó que no era apta para aquellos trabajos que requiriesen cierta cualificación:

Es evidentequeel trabajoquesearranca por el miedoa los castigos esineficazeimproductivo [...] La esclavitud es incompatible con un estado elevado de las artes de la vida y con una eficiencia aceptable del trabajo. Los países esclavistas dependen por lo general de extranjeros para todos aquellos productoscuyamanufactura requierehabilidad.La esclavitudsinesperanza embrutece efectivamente el intelecto [...] El trabajo asalariado es, por lo general, en tan gran proporción más eficiente que el del esclavo, que el patrón puede pagar una cantidad más elevada en salarios de lo que costaría el mantenimiento de los esclavos y, sin embargo, ganar en el cambio ${ }^{24}$.

No obstante, al igual que Smith, Mill hizo una excepción con las colonias azucareras del Caribe, pues apuntó que la compensación pagada a los propietarios de esclavos tras la abolición podía no haber sido suficiente dada la alta rentabilidad del trabajo esclavo en la producción de azúcar. Para Mill, como el salario del trabajador libre era función "de la proporción que [existiese] entre la población trabajadora y el capital y la tierra", en las Antillas, "islas poco pobladas y de suelo muy rico, no [había] duda de que el trabajo de los esclavos producía ganancias mucho mayores que el de los hombres libres" en la producción azucarera, que requería además de grandes cantidades de mano de obra ${ }^{25}$. Asimismo, reconocía que la producción de azúcar no habría crecido con tanta rapidez de no haber existido la esclavitud, y añadía -de forma sorprendente- que había "tribus tan adversas a la actividad regular y sostenida, que la vida industrial apenas [podía] introducirse en ellas, a menos que [fueran] conquistadas y se [convirtieran] en esclavos"26.

La segunda aproximación de Mill a la esclavitud fue en respuesta al "Discurso ocasional sobre la cuestión negra" que había publicado en 1849 su hasta entonces amigo el ensayista escocés Thomas Carlyle (1795-1881 $)^{27}$. Carlyle -influido en parte por McCulloch, al que había conocido en $1822^{28}$ - señaló que lo sucedido en las Indias Occidentales tras la emancipación de los esclavos mostraba claramente que esta había sido una equivocación, pues los negros, una vez liberados, habían caído en la indolencia y la holgazanería que les era consustancial, con lo que la prosperidad de las plantaciones de azúcar se había venido abajo. Desde una posición paternalista y acentuadamente racista que partía de afirmar la inferioridad de los africanos, Carlyle consideraba que estos eran perezosos y tenían una natural actitud desdeñosa hacia el "sagrado" trabajo, que sus deseos eran tan limitados que no reaccionaban a los incentivos del mercado, y que podían proveerse de las subsistencias básicas con muy poco esfuerzo, por lo que si no se les obligaba a trabajar mediante la esclavitud no producirían ${ }^{29}$.

24 Mill 1985, p. 233, 235.

25 Mill 1985, p. 235.

26 Mill 1985, p. 233.

27 Carlyle 1849.

28 Véase Groenewegen 2001, p. 79, 89.

29 Carlyle hizo su famosa referencia a la economía como "ciencia lúgubre" al hilo de su artículo 
Mill se apresuró a responder a Carlyle, pues temía que su defensa del sistema esclavista tuviera un impacto importante en el Sur de Estados Unidos, donde efectivamente sería luego reimpresa y ampliamente comentada ${ }^{30}$. En una carta al director enviada a la Fraser's Magazine, Mill afirmaba la igual dignidad de todos los seres humanos y destacaba la gran diferencia existente entre esclavos -víctimas de la tiranía más absoluta- y trabajadores libres, incluso aunque las condiciones de vida de estos últimos fueran muy malas. Es decir, hacía ver que la comparación entre los negros africanos y los blancos irlandeses, que Carlyle realizaba a menudo, carecía completamente de sentido. Por otra parte, Mill cuestionaba que el trabajo, sacralizado por Carlyle, fuera bueno en sí mismo, y también que los negros antillanos estuvieran malgastado la tierra por cultivar alimentos básicos para sí mismos -como las calabazas- en vez de azúcar u otros productos para los europeos ${ }^{31}$. En realidad, Mill asumía la postura propia del economista que cree que los individuos hacen elecciones subjetivas -como la de más ocio en vez de trabajo- que nadie está en condiciones de cuestionar ${ }^{32}$.

Instigado por Mill, el economista irlandés John Elliott Cairnes (1823-1875) se ocupó de la esclavitud con bastante detenimiento en El poder esclavista (1862), en referencia a los estados confederados y en el contexto de la Guerra de Secesión norteamericana. El argumento fundamental de Cairnes era que la rentabilidad del sistema esclavista - que requería abundancia de tierra fértil y cultivos intensivos en mano de obra con economías de escala que favorecían plantaciones de gran tamañoera sólo temporal. Tarde o temprano la tierra se agotaría y los graves defectos de la mano de obra esclava (poco incentivo al trabajo, nula cualificación y falta de versatilidad), que desaconsejaban su uso en la manufactura, acabarían siendo dominantes, haciendo inviable económicamente la esclavitud. Es decir, el propio desarrollo económico iría destruyendo gradualmente la utilidad de la esclavitud incluso en países en los que dicha institución había sido en principio muy ventajosa en términos económicos. Por otra parte, aunque la emancipación podría tener a corto plazo un efecto económico negativo, el resultado acabaría siendo finalmente beneficioso, como lo demostraba el caso de Jamaica ${ }^{33}$. En cualquier caso, lo más relevante es que Cairnes distinguió claramente entre los resultados de la esclavitud para los propietarios individuales y para el país en su conjunto: era posible que los primeros se enriquecieran notablemente mientras la sociedad globalmente considerada se empobrecía, pues el sistema esclavista era incompatible con el pleno desarrollo de los recursos nacionales ${ }^{34}$.

La crítica posterior a Cairnes se centró en destacar que este autor nunca estuvo

sobre la "cuestión negra" (Levy, 2001).

30 Levy 2001, p. 23-4.

31 Mill 1984.

32 Levy y Peart 2001, p. 3. En 1865 Mill y Carlyle volverían nuevamente a enfrentarse a raíz del caso del gobernador E.J. Eyre, quien había dirigido una feroz represión contra antiguos esclavos antillanos en Jamaica en la que murieron más de cuatrocientas personas.

33 Groenewegen 2001, p. 88-9.

34 Cairnes 1862, p. 60. 
en Estados Unidos y que empleó de forma sesgada unas fuentes muy limitadas para llegar a lo que pretendía demostrar a priori ${ }^{35}$. No obstante, recientemente esta crítica ha sido matizada, señalando que Cairnes intentó hacer una exposición equilibrada tomando en consideración visiones contrapuestas, como por ejemplo las anotaciones de viaje de Frederic Law Olmsted por el Sur esclavista (que dibujaban una economía en declive debido a su singular estructura productiva) o las compilaciones de ensayos y datos estadísticos de James D.B. De Bow (que intentaban promover la expansión de la industria y el comercio en el Sur y proteger el sistema esclavista como parte inherente del modo de vida sureño) ${ }^{36}$.

En definitiva, salvo contadas excepciones como las de McCulloch o Merivale, cabe afirmar que hubo un amplio consenso entre los economistas clásicos en que el trabajo esclavo era siempre menos productivo que el libre, y que tal ineficiencia desde el punto de vista de la sociedad en su conjunto resultaba a la larga poco compatible con el deseado objetivo de lograr una creciente prosperidad general y el mayor crecimiento económico posible. Sin embargo, la cuestión del menor coste de la mano de obra esclava frente a la libre -y por tanto, de su mayor rentabilidad para el propietario individual- resultó ser más controvertida. En el capítulo XII de la quinta edición de su Manual de economía política, el profesor de Cambridge Henry Fawcett (1833-1884), a veces calificado como el último de los economistas clásicos, sintetizó la que había sido la postura de la escuela respecto a la esclavitud: era siempre ineficiente y a menudo poco rentable ${ }^{37}$.

Entre los críticos de la economía clásica también hubo autores que dedicaron atención a la esclavitud y la atacaron en términos económicos, aunque por distintos motivos. Jean Charles Leonard Simonde de Sismondi (1773-1842) defendió en sus Estudios de economía politica (1837), basándose en Say y Comte, que la aparente prosperidad sistema esclavista de plantación sólo se sostenía por la protección y el apoyo de la metrópoli, y añadió que la esclavitud debia ser abolida sin indemnización alguna para los propietarios, pues los esclavos no eran capital ${ }^{38}$. Henry Charles Carey (1793-1879), miembro de la escuela proteccionista americana del siglo XIX y asesor económico de Lincoln, argumentó en El comercio de esclavos ( 1853) que el modelo esclavista había actuando en realidad como un instrumento para fortalecer la industria británica: las colonias británicas de las Indias Occidentales habían quedado especializadas en la producción esclavista de azúcar para la exportación, sin dejar sitio al desarrollo de un sector manufacturero y provocando además un agotamiento gradual del suelo ${ }^{39}$. Finalmente, Karl Marx (1818-1883) pensaba -como Smith y Mill- que el trabajo esclavo era ineficiente o poco productivo, aunque consideraba que el sistema

35 Véase, por ejemplo, Miller 1964, p. 340-1.

36 Maas 2015, p. 183.

37 Fawcett 1876, p. 304-11. Parece que la inmensa mayoría de los economistas norteamericanos del siglo XIX, pese a sus diversos enfoques teóricos, se situaron respecto a la esclavitud en una línea similar a la de los clásicos. Lo mismo cabría decir del fundador del historicismo alemán, G.F. Roscher (Hummel 2012, p. 50-2, 60-1).

38 Steiner 2003, p. 140-1.

39 Groenewegen 2001, p. 87-8. 
capitalista esclavizaba en última instancia a todos: "la esclavitud disfrazada de los asalariados en Europa exigía, a modo de pedestal, la esclavitud sans phase en el Nuevo Mundo" $^{40}$. No obstante, Marx distinguió claramente entre la esclavitud indirecta del proletariado y la esclavitud radical de los africanos en Brasil, el Caribe o el Sur de Estados Unidos, pues la mayor libertad y movilidad del trabajador asalariado contrastaba con el total sometimiento a un amo y la venta sin su consentimiento del africano. Precisamente, situó la esclavitud radical en América como un elemento clave en el afianzamiento del capitalismo industrial:

La esclavitud directa es el eje central de nuestra industrialización en la misma medida que la maquinaria, el crédito, etc. Sin la esclavitud no se obtiene algodón, sin algodón no hay industria moderna. La esclavitud es lo que ha dado valor a las colonias; las colonias son lo que ha creado el comercio mundial; el comercio mundial es la condición necesaria para la maquinaria industrial a gran escala ${ }^{41}$.

\section{Las etapas del debate abolicionista en España según un economista antiesclavista}

El economista y destacado abolicionista Gabriel Rodríguez (1829-1901) realizó en 1887 una breve historia del movimiento antiesclavista español durante el siglo $\mathrm{XIX}^{42}$. La narración es incompleta pero interesante, tanto por su propuesta de división en etapas del movimiento como por incidir en el papel desempeñado por los economistas. Distinguió tres etapas: los precursores (1800-1864), la propaganda colectiva organizada (1864-1870), y las reformas legislativas (1870-1886).

En la primera, mencionó el discurso de 1802 de Isidoro de Antillón, publicado en 1811 , en el que se proponía la abolición tanto de la trata como de la esclavitud de una forma gradual. En cuanto a los economistas de la primera mitad del siglo XIX destacó a Álvaro Flórez Estrada, que quería "ir a la abolición de la esclavitud "no permitiendo que en lo sucesivo se hiciera el tráfico de esclavos»"43. Sin embargo, no prestó suficiente atención a la labor de José Antonio Saco y Ramón de la Sagra $^{44}$. Al final de esta primera etapa subrayó la actividad pro-abolicionista del político puertorriquense Julio Vizcarrondo (1829-1889), fundador de la Sociedad Abolicionista Española. Este no halló en un principio seguidores para su causa con la excepción de "una acogida entusiasta en los jóvenes que constituían el grupo llamado de los economistas, y que vivían por entonces separados de los partidos, obrando sobre la opinión por medio de la Sociedad de Economía Política, y de la Asociación para la Reforma de los Aranceles de Aduanas"45.

40 Marx 1975, p. 949. También Marx 1975, p. 307, 914n; Rodríguez Braun 2011, p. 41.

41 Marx 1972, p. 24.

42 Dos referencias para situar en su contexto a los autores seleccionados en este trabajo y que inciden en los aspectos económicos: Maluquer 1971 y Schmidt-Nowara 1998.

43 Rodríguez 1887, p. 326-7.

44 También destacó las propuestas antiesclavistas presentadas en las Cortes de Cádiz de 1811 y que los "neo-católicos" en las Cortes de 1854-6 consideraron la esclavitud necesaria para cultivar principalmente cacao, azúcar y café (Rodríguez 1887, p. 331-4).

45 Rodríguez 1887, p. 336. También dijo lo mismo Sanromá 1887-1894, II, p. 343. 
La segunda etapa comenzó con la constitución de la citada Sociedad en una reunión celebrada en 1864, a la que asistieron los principales miembros de la Escuela Economista y, por supuesto, el propio Rodríguez. Este subrayó de nuevo que "el núcleo de la Sociedad estaba formado por la juventud de la Escuela Economista, cuyos hombres pertenecieron todos desde el principio a la Sociedad, teniendo algunos de ellos puestos en la primera Junta directiva, como Moret, Bona, Sanromá, y otros"46. Rafael María Labra (1840-1918), al que le unía una estrecha relación con estos autores, también se refirió a esta primera reunión y señaló que asistieron a la misma "los economistas Bona, Figuerola, Gabriel Rodríguez, Sanromá, Alonso de Beraza y Carreras y González"47, adhiriéndose también -entre otros- Segismundo Moret. Esta segunda etapa terminó justamente con la aprobación de la ley preparatoria de abolición de la esclavitud de 1870, también llamada Ley Moret.

La tercera etapa fue la más importante, pues en ella quedó abolida la esclavitud en Puerto Rico ( 1873) y Cuba (1886). Ello sucedió tras una intensa actividad de la Sociedad Abolicionista, que además tuvo que vérselas con la Liga Nacional, creada en 1873 para contrarrestar las iniciativas abolicionistas ${ }^{48}$.

De esta clasificación de Rodríguez se deduce la importancia que tuvieron los economistas y sus argumentos económicos en la causa abolicionista, como se expondrá en los siguientes epígrafes. Como señaló un antiesclavista en 1866, aunque "la religión con sus dogmas", "la moral con sus máximas", "la filosofía con sus principios" y la "política con sus consejos" habían dado argumentos contrarios a la esclavitud, la economía -“con sus verdades"- había puesto "al alcance del más rudo los requisitos y condiciones para que el trabajo manual [fuera] fecundo y productivo", y tales circunstancias no se cumplían en el sistema esclavista ${ }^{49}$. Es decir, para los economistas trabajo y libertad iban indisolublemente unidos ${ }^{50}$. En definitiva, el debate español fue relevante porque giró en torno a si se podía admitir -como planteó Smith- una excepción en la que la esclavitud podría ser rentable, la de las plantaciones antillanas de tabaco y, sobre todo, de azúcar.

\section{Primera etapa (1800-1864): los precursores Saco y Sagra}

En el primer tercio del siglo XIX se inició tímidamente el movimiento abolicionista español de la mano de Antillón, algunos liberales de la Cortes de Cádiz (Quintana, Guridi Alcocer, Argüelles y Mejía), Blanco-White y Varela. Pero esta fase inicial -que ya ha sido bastante estudiada- está fuera del ámbito de interés de este trabajo por dos razones ${ }^{51}$. Primero, porque el debate giró entonces esencialmente en torno al mejoramiento de las condiciones de vida de los esclavos y la abolición de la trata: aunque hubo algunas apelaciones difusas a la abolición de la esclavitud -como las

46 Rodríguez 1887, p. 337.

47 Labra 1889, p. 67.

48 Rodríguez 1887, p. 347.

49 Hernández Iglesias 1866, p. 7-8.

50 Menéndez Acebal 1875, p. 104.

51 Dos trabajos recientes sobre este tema: Berquist 2010 y Perdices y Ramos 2014. 
de Guridi Alcocer o Varela-, lo que de verdad estaba en discusión era la abolición del tráfico de esclavos, que se había disparado desde su liberalización en 1789 y que los ingleses parecían decididos a erradicar. Y segundo, porque los argumentos económicos estuvieron prácticamente ausentes en este periodo: dominaron los de carácter moral, humanitario, religioso o incluso político (el temor a una insurrección), pero no se discutió sobre las ventajas del trabajo libre frente a la mano de obra esclava o sobre los condicionantes del modelo productivo de la gran plantación esclavista. Sólo Arango y Parreño, en su defensa inicial de la continuación de la trata aludió fugazmente a cuestiones tales como la escasez de mano de obra en Cuba o la posible ruina de las explotaciones azucareras si se interrumpía la afluencia de nuevos esclavos. Posteriormente, el propio Arango -propietario de un gran ingenio azucarero, lector de Smith y amigo de Humboldt- pasaría también a abogar por la abolición efectiva de la trata, pero no por razones económicas, sino por constatar que se trataba de una opción ya entonces asumida por las principales potencias coloniales.

Por los motivos que acaban de apuntarse, nos centraremos en los argumentos económicos frente a la esclavitud expuestos a mediados del siglo XIX por dos notables economistas, Sagra y Saco, a los que, como se ha dicho, Rodríguez apenas prestó atención. Y es que el debate económico sobre la abolición de la esclavitud comenzó verdaderamente en 1845, cuando -con la ley de 2 de mayo- se instauraron por primera vez medidas concretas para combatir la trata, que ya había sido legalmente abolida en 1817 y 1835. Aunque la trata ilegal continuó de facto hasta el entorno de 1865, desde 1845 se empezó por fin a aceptar de forma generalizada que el final efectivo del tráfico negrero era ya inevitable y llegaría más pronto que tarde. Y una vez cerrada dicha cuestión, podía plantearse la abolición de la institución en sí, que ya había tenido lugar en las colonias inglesas y estaba en vías producirse en las francesas.

El inclasificable Ramón de la Sagra ( 1798-1871) -geógrafo, economista, sociólogo y naturalista- conoció bien la realidad cubana, lo que le permitió hablar del tema esclavista con pleno conocimiento de causa: antes de su amplio viaje por la isla de 1859-60, había sido profesor de una cátedra de botánica agrícola en La Habana entre 1823 y 1835, dirigiendo también el jardín botánico de la ciudad y fundando la revista Anales de ciencias, agricultura, comercio y artes. De esta larga estancia de doce años nacería la Historia económico-politica y estadística de la isla de Cuba (1831), precedente de los dos primeros tomos de una obra mucho más ambiciosa en catorce volúmenes que empezó a publicarse en París en 1838, Historia física, politica y natural de la isla de Cuba. No obstante, fue en De los efectos de la supresión del tráfico negrero (1845) donde abordó específicamente la esclavitud y sintetizó su visión al respecto de modo mucho más amplio a lo sugerido por el título, aunque sin citar nunca explícitamente sus posibles fuentes intelectuales.

Al margen de condenar la institución por razones morales y políticas -pues era "contraria a las leyes de la naturaleza", suponía una "monstruosa desigualdad 
de derechos", y constituía una amenaza potencial de rebelión violenta ${ }^{52}-$, Sagra se oponía a la esclavitud en las Antillas españolas tanto por el tipo de modelo económico global al que iba asociada, como por los defectos económicos específicos de la mano de obra esclava -situándose así en la línea smithiana y anticipando algunos de los planteamientos específicos posteriores de Cairnes referidos al sur de Estados Unidos.

Por un lado, Sagra consideraba que el sistema cubano de plantación esclavista azucarera -basado en grandes latifundios, amplia dotación de tierras fértiles, constante crecimiento del número de esclavos africanos, y trato comercial privilegiado- era sinónimo deforestación, monocultivo y mono-exportación. Pero además sus bases eran frágiles y se cernían sobre él serias amenazas: por ejemplo, el tráfico negrero había sido ilegalizado y la emancipación era un proceso en marcha que parecía imparable (ya había tenido lugar en las colonias inglesas del Caribe y estaba en vías producirse en las francesas) $)^{53}$; también había signos claros de que se habían ido depauperando tierras en la isla; y -por último- la competencia de otras zonas productoras de caña fuera del área caribeña, como Java o la India, era creciente, al tiempo que iba arraigando en Europa el cultivo de la remolacha azucarera ${ }^{54}$. En definitiva, aunque el sistema esclavista de plantación aún era rentable para los hacendados en aquel momento, sus cimientos se estaban erosionando poco a poco. A ello se unía que los latifundios de caña absorbían y concentraban una gran cantidad de capital que, bien repartido en otros usos, podía dar lugar a una mayor actividad general que beneficiase a todas las comarcas ${ }^{55}$.

Por otro lado, el empleo de mano de obra esclava obligaba a adoptar un sistema muy simple de cultivo y era incompatible con una agricultura científica y sofisticada que diera lugar a la continua introducción de nuevas técnicas y perfeccionamientos. El esclavo, sin ningún incentivo, siempre procuraba "disminuir el peso de la tarea, ya practicándola mal, ya sustrayéndose a ella", y resultaba "imposible conseguir esmero, inteligencia y amor al trabajo de unos seres degradados" por su condición ${ }^{56}$. En tales circunstancias, parecía mucho más importante tener supervisores que destacasen por su crueldad antes que por sus conocimientos agronómicos ${ }^{57}$. Es decir, el edificio de la agricultura azucarera se había elevado sobre las "bases absurdas de la fuerza, la ignorancia y la imprevisión", pues se había optado por "la estupidez de los cultivadores como garantía de seguridad de las fincas, la fuerza material como único elemento para el cultivo, y la rutina como sola ley agrícola"58. Sin embargo,

52 Sagra 1845, p. 9.

53 Sagra 1845, p. 78.

54 Sagra 1845, p. 13, 77.

55 Sagra 1845, p. 17.

56 Sagra 1845, p. 11, 15.

57 Sagra 1845, p. 10, no consideraba que los africanos fueran indolentes por naturaleza, sino que creía que los pueblos mostraban distintos grados de actividad según el nivel de desarrollo en el que se encontraban. Tampoco opinaba que los negros fueran intelectualmente inferiores: su "letargo intelectual" se debía a las condiciones del régimen esclavista (p. 12).

58 Sagra 1845, p. 12. 
el verdadero avance agrícola debía fundarse precisamente en lo contrario: atención a la formación de los operarios, introducción de máquinas, principios racionales de cultivo (frente a práctica ciega), y consideraciones previsoras para asegurar una producción constante que no empobreciese el suelo y acabara a la larga inutilizándolo. En suma, con el sistema esclavista se estaba muy lejos de aprovechar plenamente las notables ventajas naturales de la isla: la producción agrícola efectiva distaba mucho de la potencial dada la gran feracidad del suelo y el buen clima.

Ante este estado de cosas -según Sagra- era necesario hacer algo con urgencia, pero la solución no era simplemente la emancipación de los esclavos, tal como dejaba claro lo sucedido en las Antillas británicas (Jamaica, Antigua, Barbados, etc.). Allí los antiguos esclavos asociaban ahora el trabajo agrícola -base de las sociedades caribeñas- con el trabajo esclavo: se había impuesto un "sello de infamia a la tierra", pues muchas tareas, por haber sido exclusivamente ejercidas durante siglos por los esclavos, habían quedado profundamente marcadas por la ignominia ${ }^{59}$. En este sentido, despertaba un especial rechazo el trabajo en las grandes plantaciones de caña y café, lo que inevitablemente había llevado a la decadencia de las explotaciones latifundistas y la caída de la producción azucarera. Además, la antigua población esclava había desarrollado un fuerte deseo de independencia personal y era reticente a contratos a largo plazo: prefería -siempre que fuera posible- el trabajo por cuenta propia en pequeñas parcelas, con cultivos no comerciales cómodos y provechosos (frutas, raíces, legumbres, etc.), y ajustándose a lo estrictamente necesario para cubrir sus necesidades básicas (lo que no suponía demasiado esfuerzo dadas las favorables condiciones de clima y fertilidad ${ }^{60}$. Frente a todo ello, los grandes hacendados habían maniobrado para boicotear a los antiguos esclavos en algunas de las colonias británicas, intentando -por ejemplo- que no se les concediesen tierras, que se restringiesen sus posibilidades de movimiento de unos territorios a otros, o que se facilitara la entrada masiva de mano de obra de China y la India; pero el resultado más evidente de tales manejos -lejos de conseguir restaurar una situación similar a la pre-emancipación- había sido generar una creciente tensión entre la población blanca de antiguos amos y la población negra de antiguos esclavos ${ }^{61}$.

A la vista de lo que había sido la experiencia inglesa en sus territorios del Caribe que acaba de describirse, era evidente que no bastaba con emancipar a los esclavos: allí la producción azucarera por brazos libres había decaído no por un vicio inherente al trabajo libre, sino por las profundas huellas que la esclavitud había dejado en los trabajadores de origen africano ${ }^{62}$. Por eso, la propuesta de Sagra para Cuba era incentivar que se asentasen masivamente en la isla colonos blancos como

59 Sagra 1845, p. 30-1. La educación que había empezado a recibir la población negra tras la emancipación reforzaba aún más sus reticencias frente a la agricultura (Sagra 1845, p. 52). A ello se unía el natural deseo de disfrute de comodidades y lujos que hasta entonces les habían sido ajenos (p. 54, 64-5).

60 Sagra 1845, p. $27-32$.

61 Sagra 1845, p. 36-42.

62 Sagra 1845, p. 77. 
propietarios de medianas y pequeñas parcelas, aplicando al cultivo maquinaria y métodos perfeccionados ${ }^{63}$; sustituir el trabajo esclavo por el trabajo asalariado (lo que a su vez aumentaría el circuito comercial por un aumento de los consumos); diversificar la producción primaria (caña, tabaco, café, algodón, seda, carne, minería, etc.) para reducir la dependencia de la exportación azucarera; promover un nivel de desarrollo similar en toda la isla (incluyendo las zonas más alejadas de la capital) con las necesarias inversiones en infraestructura (desagüe, comunicaciones, etc.); e independizar la fabricación de azúcar, concentrando el procesamiento de toda la caña cosechada en un pequeño número de ingenios de gran tamaño que aprovechasen las economías de escala (como se hacía en la Java holandesa). No obstante, el propio Sagra reconocía la dificultad de cualquier cambio ante la debilidad del Estado y la fuerza de los intereses creados en torno a la continuación del deficiente y amenazado sistema esclavista azucarero de grandes latifundios ${ }^{64}$.

José Antonio Saco (1797-1879), uno de los intelectuales más importantes de la Cuba del siglo XIX, fue al igual que Sagra -con quien mantuvo una intensa polémica literaria ${ }^{65}$ - un autor polifacético. Destacó, entre otros ámbitos, en el periodismo, la historia y el ensayo sobre temas socioeconómicos, y además de conocer de primera mano la realidad cubana, tuvo una experiencia cosmopolita al haber viajado por distintos países europeos y haber residido en ciudades como Nueva York, París o Madrid. Gran estudioso del fenómeno esclavista, al final de su vida publicó en París y Barcelona, en tres tomos, una Historia de la esclavitud desde los tiempos remotos hasta nuestros días (1875-77), y poco más tarde el primer volumen de su Historia de la esclavitud de la raza africana en el Nuevo Mundo y en especial en los países américohispanos (1879). Pero su trabajo más relevante sobre la esclavitud desde un punto de vista económico fue La supresión del tráfico de esclavos africanos en la isla de Cuba, publicado en París en 1845 y reeditado en Nueva York en 1853, donde -a pesar del título- iba más allá de la mera cuestión de la trata ${ }^{66}$. En principio, el objetivo de Saco, que dejaba explícitamente a un lado consideraciones morales, era demostrar dos cosas: por un lado, que la continuación de la trata ilegal conduciría a que se perdiera Cuba como colonia española, y por otro, que la agricultura cubana no necesitaba del tráfico de esclavos y no se vería arruinada por su interrupción. Sin embargo, al hilo

63 En contraste con la visión de Sagra, que pretendía "blanquear" la isla e introducir reformas que fortaleciesen el vínculo con España, Humboldt, en su Ensayo político sobre la isla de Cuba (1826), propuso incorporar a la isla a una posible confederación africana de las Antillas constituida por territorios caribeños - continentales e insulares- que hubiesen estado marcados por la plantación y la esclavitud (Domínguez 2015, p. 146, 150). La idea de Sagra de fomentar la colonización blanca que también defendieron autores como Saco o Vázquez Queipo- no era nueva: venía proponiéndose ya desde finales del siglo XVIII y daría lugar a proyectos concretos: Naranjo (2005, p. 108-78).

64 Sagra 1845, p. 16, 83-7.

65 La polémica, que tuvo lugar en La Habana en 1829, giró aparentemente en torno a las poesías de José María Heredia, pero en realidad apuntaba a un tema de mayor calado, el de la identidad cubana: Aguilera 2005.

66 Como indica Torres-Cuevas (1984, p. 78-9, 113, 134), este estudio tenía claros antecedentes en otros trabajos previos sobre la esclavitud publicados por Saco en la década de 1830. 
de esta última cuestión dejó ver sus argumentos económicos contra la esclavitud, si bien él no pensaba en una abolición inmediata, sino progresiva ${ }^{67}$.

Respecto al peligro que suponía la continuación de la trata para la conservación de Cuba como colonia española, Saco consignaba el continuo incremento de la población negra -libre y esclava- frente a la blanca, que en 1841 ya se había visto superada por la primera. Recordaba la exitosa rebelión de esclavos en Haití y las numerosas insurrecciones en Jamaica que sólo a duras penas habían podido ser sofocadas, y consideraba que, dadas las apetencias de otras potencias extranjeras sobre Cuba, estas podrían aprovechar la inestabilidad interna de la isla para hacerse con su control ${ }^{68}$. Por todo ello, su propuesta -coincidente en este punto con la de Sagra- era fomentar la población blanca en Cuba.

En cuanto a la supuesta dependencia de la agricultura cubana del comercio de esclavos, esta se basaba en tres premisas falsas pero frecuentemente repetidas: la extremada dureza del cultivo y procesamiento de la caña, que únicamente los africanos bajo régimen de esclavitud podían llevar a cabo dada su notable fortaleza física; el peculiar clima, al que sólo los africanos estaban plenamente adaptados; y los elevados jornales de la mano de obra libre en la isla, que hacían que su empleo en las plantaciones de caña resultase económicamente inviable ${ }^{69}$. Frente a lo primero, Saco argumentaba que el azúcar de caña se producía en distintos lugares de Asia sin utilizar esclavos africanos, y que también se había producido anteriormente en México sin mano de obra esclava; por otra parte, había ya blancos trabajando en esas tareas agrícolas en el Caribe, y además en un futuro se irían introduciendo nuevos instrumentos y maquinaria que facilitarían cada vez más las labores de elaboración de $a_{u \text { úcar }}{ }^{70}$. Para refutar las supuestas dificultades impuestas por las condiciones climáticas, Saco se refirió al amplio asentamiento de europeos en todas las Antillas a lo largo de varias generaciones ${ }^{71}$. Y en respecto a los elevados jornales, Saco entró a discutir la rentabilidad y eficiencia del trabajo libre frente al esclavo, tal como se verá a continuación.

A primera vista, era evidente que la mano de obra esclava resultaba entonces más barata en Cuba, y ello era consecuencia del propio comercio masivo de africanos: pese a la prohibición formal de la trata, la afluencia de esclavos había sido de facto constante y cuantitativamente importante durante años, por lo que los trabajadores libres dedicados al cultivo del azúcar eran lógicamente escasos y sus salarios relativamente altos $^{72}$. Sin embargo, la elección del tipo de mano de obra más conveniente no podía reducirse a la comparación entre el coste de manutención del esclavo y el jornal del trabajador libre. De hecho -según Saco- a la larga sería más

67 Saco 1853, p. 173-4, 177.

68 Saco 1853, p. 212-4, 223. Esta postura de Saco tiene un claro antecedente en la de su maestro, el sacerdote y profesor cubano Félix Varela, quien ya en 1822, siendo diputado en las Cortes de Madrid, había planteado algo similar (Varela 2016, p. 136-40).

69 Saco 1853, p. 178.

70 Saco 1853, p. 178-81.

71 Saco 1853, p. 182-94.

72 Saco 1853, p. 195. 
seguro y rentable cultivar la caña con trabajo libre dadas sus evidentes ventajas sobre la mano de obra esclava, pero siempre que desde el gobierno se definieran unas condiciones adecuadas (eximir de impuestos al azúcar y a los productos de primera necesidad consumidos por los operarios, mejorar las comunicaciones interiores, fomentar el perfeccionamiento de las tareas favoreciendo la introducción de nueva maquinaria, incentivar la entrada de nuevos colonos, etc. $)^{73}$.

En efecto, el trabajo libre de colonos blancos -que los hacendados podrían sustituir en cualquier momento a conveniencia-supondría contar con cultivadores mejor formados y más interesados, fieles y responsables que los indolentes y negligentes esclavos, solo dispuestos a laborar ante una estrecha y costosa vigilancia coactiva; asimismo, los hacendados evitarían los frecuentes robos de víveres y azúcar, así como los muchos gastos que en el régimen esclavista recaían sobre los amos debido a contingencias varias (fugas, enfermedades, matrimonios, bautismos, entierros, sublevaciones, etc.). Pero además, continuar con el trabajo esclavo extendía sobre las explotaciones azucareras un velo de inseguridad e incertidumbre relacionado con el final efectivo del tráfico negrero ilegal y con la eventual abolición definitiva de la institución de la esclavitud, que habría de llegar tarde o temprano ${ }^{74}$. Por otra parte, Saco consideraba que no era indispensable un gran tamaño de las explotaciones azucareras para que estas fueran rentables, y -al igual que Sagraabogaba por separar las labores de cultivo de la caña de las de su procesamiento, las cuales podían concentrarse ventajosamente en unos pocos ingenios ${ }^{75}$.

\section{Segunda etapa (1864-1870): se abre el debate}

Esta segunda etapa se inició durante los últimos años en el poder de Ramón María Narváez, quien con su política represiva contra toda actividad considerada subversiva clausuraría en 1866 la Sociedad Abolicionista y su periódico, El Abolicionista. Continúo con la revolución Gloriosa de 1868, en la que algunos de los miembros de la Escuela Economista llegaron al poder. Y finalizó con la aprobación de la Ley Moret de 1870, que promulgó la libertad de los esclavos que fueran sexagenarios, niños o del Estado, pero que no convenció a los abolicionistas y contentó solo parcialmente a los esclavistas. Fue un periodo, en definitiva, de intenso debate sobre la esclavitud, en el que las consideraciones económicas alcanzaron relevancia.

\section{Esclavismo puro y abolicionismo gradualista: de Ferrer de Couto a Armas y Céspedes}

El campo esclavista contó con algunos autores que se pronunciaron abiertamente a favor de la esclavitud -llamándola a veces eufemísticamente "trabajo forzoso"y otros que solicitaron su abolición gradual, aunque en realidad muchos querían preservar la esclavitud lo máximo posible. Entre los primeros tuvo un lugar principal José Ferrer de Cuoto, militar gallego de ideas conservadoras, fiel defensor

73 Saco 1853, p 196.

74 Saco 1853, p. 197.

75 Saco 1853, p. 198-200. 
de la monarquía isabelina y conocido por sus escritos sobre la historia de la Marina española. En 1864 comenzó a publicar en Nueva York El Cronista, en cuyas páginas defendió los intereses españoles en América. Y también desde esta ciudad y en plena guerra de Secesión, publicó Los negros en sus diversos aspectos y condiciones, tales como son, como se suponen que son y cómo deben ser (1864). Destacó en las filas esclavistas por exponer con claridad los argumentos económicos a favor de la esclavitud -mezclándolos con argumentos racistas- y por tener lectores a ambos lados del Atlántico. Así, su libro se publicó también en inglés con el polémico título Enough Of War!: The Question Of Slavery Conclusively And Satisfactorily Solved, As Regards Humanity At Large And The Permanent Interests Of Present Owners (1864). Sus argumentos estaban en la misma línea que los de McCulloch y Carlyle -a los que no citó-, y fueron objeto de crítica por parte de los miembros de la Escuela Economista y de Labra, que a su vez tampoco citaron a Ferrer ${ }^{76}$. En cualquier caso, los textos de Carlyle habían sido reproducidos en revistas americanas, con lo que sin duda Ferrer -desde Nueva York- tuvo acceso a ellos ${ }^{77}$.

Ferrer sorprende en la actualidad no sólo por su racismo, sino porque prefirió hablar de "rescate" y "trabajos forzosos" en vez de trata y esclavitud. "Rescate", más que trata, porque los europeos realmente habían hecho una obra humanitaria, civilizadora y filantrópica al rescatar a los africanos de una vida en el más puro estado de barbarie en sus territorios de origen para traerlos a América. Y es que Ferrer consideraba que la raza negra estaba "degenerada"78 y "envilecida", y tenía "en la guerra su estado normal y en los sacrificios humanos y el canibalismo las recompensas de los vencedores"79, a lo que había que añadir "la ínfima porción de inteligencia que Dios [había] puesto" en su naturaleza ${ }^{80}$. Todo ello justificaba que a los africanos se les "rescatase" y luego se les sometiese a un régimen de trabajos forzados ${ }^{81}$. Además, para Ferrer el fin último de los tratados de abolición de la trata firmados con Inglaterra en 1817 y 1835 había sido destruir las colonias españolas, pero se había continuado con dicho tráfico "por necesidad de la agricultura" ${ }^{2}$.

Prefirió hablar de "trabajos forzosos" y no de esclavitud porque en el caso español -desde el Descubrimiento- la legislación había sido suave gracias a la influencia del cristianismo, hasta el punto de que "casi [se podía] decir técnicamente" que la esclavitud no había existido ${ }^{83}$. Dada la humanidad con la que los africanos habían sido tratados por las leyes, contemplándose incluso la posibilidad de adquirir su libertad, se podía afirmar que estaban bajo un "régimen de colonos libres sujetos a razonable contrata" y no de esclavitud. Y no solo las leyes habían sido beneficiosas

76 También publicó en Nueva York en 1872 Cuba puede ser independiente.

77 Véase The Carlyle-Mill "Negro Question" Debate.

78 Ferrer 1864a, p. 21.

79 Ferrer 1864a, p. 15.

80 Ferrer 1864a, p. 162.

81 Asimismo comparó a los africanos y sus prácticas con las de los indios americanos, e hizo una referencia al debate sobre la esclavitud del siglo XVI (Ferrer 1864a, p. 26).

82 Ferrer 1864a, p. 111.

83 Ferrer 1864a, p. 49. Los capítulos III y IV los dedicó a la legislación esclavista. 
para los africanos, sino que su nivel de vida era más que aceptable. Los esclavos de las plantaciones vivían mejor que los jornaleros castellanos, pues los primeros trabajaban menos horas, se les mantenía, e incluso en algunas ocasiones se les daba un pequeño terreno para explotarlo en su propio provecho; en cambio, a los segundos sus salarios apenas les llegaban para sustentarse ${ }^{84}$. Aunque existía la posibilidad del castigo físico para "ordenar ideas confusas, desarraigar costumbres feroces, y mantener en buena disciplina grandes masas de gente peligrosa" ${ }^{15}$, casi nunca se acudía a él; además, los africanos siempre habían sido protegidos por el síndico de los esclavos ${ }^{86}$.

Este régimen de "disciplina social" de Cuba y Puerto Rico, que hacía trabajar a los esclavos de raza negra proclives al ocio, contrastaba con el que existía en los territorios independizados de España o en las colonias británicas y francesas donde se había abolido la esclavitud. El caso de Santo Domingo mostraba claramente que tras la abolición se habían introducido "ciertos hábitos de vagancia casi de todo punto incorregible" 87 . Es decir, como el clima daba lo básico para vivir, cuando se liberó a los esclavos africanos estos volvieron "fácilmente al estado de su primitiva rusticidad" y abandonaron "el trabajo por completo"88. Es más, el régimen de libertad acababa teniendo consecuencias nefastas incluso para los antiguos esclavos:

Siendo relativos los productos del trabajo y la riqueza de los propietarios, y relativos también el número de los trabajadores y los medios de su manutención, si al orden establecido, que mantiene la disciplina del trabajo, lo reemplaza la voluntad individual, que destruye dicha disciplina, y de esto resulta naturalmente el decrecimiento de los agentes productores, sin que el de los consumidores disminuya, lejos de hacer bien a la clase que se trata de favorecer, se la perjudica en sumo grado; y de esto han dado elocuente testimonio las colonias de los mismos ingleses en América ${ }^{89}$.

En suma, la abolición del "piadoso trabajo forzoso" solo traería consecuencias negativas, siendo la principal la caída de la producción, como se había podido apreciar en aquellas colonias o países americanos en donde se había llevado a cabo. En primera instancia se había producido una "falta de brazos" y de ahí había provenido

el apocamiento de su agricultura; la merma del laboreo de sus minas; el aumento del precio de los jornales a una altura fabulosa, y el abandono de muchísimas industrias que [había] aniquilado el comercio; por cuyas causas, todas tan conducentes al menoscabo de su riqueza y al acrecentamiento de un malestar que apenas [tenía] cura, en la política se [había buscado] un remedio social, y en el merodeo de los destinos y en las violencias del estado militar beligerante, los caudales que antes [habían producido] el trabajo y las más legítimas industrias ${ }^{90}$.

84 Ferrer 1864 a, p. 92-3.

85 Ferrer 1864a, p. 95.

86 Ferrer 1864a, p. 96.

87 Ferrer 1864a, p. 87.

88 Ferrer 1864 a, p. 87.

89 Ferrer 1864a, p. 106.

90 Ferrer 1864a, p. 7. 
Dos ejemplos muy significativos -siempre sacados a relucir por los esclavistas e ilustrativos de las consecuencias del trabajo libre - eran Jamaica y Haití. En Jamaica la población había disminuido considerablemente después de la abolición ${ }^{91}$, pero en Haití los perjuicios habían sido aún mayores: “En 1790 las exportaciones ascendían a veintiocho millones de pesos [...] y [entonces] las declaraciones oficiales más exageradas apenas las [hacían] exceder de dos millones y medio"92; por otra parte, los "frutos y el comercio [habían] desaparecido de Haití desde que se [había] hecho independiente, y sus moradores [habían] retrocedido al paganismo africano"93.

Resumiendo, Ferrer no estaba a favor del trabajo libre de los africanos porque por "salvar los principios" que lo sustentaban se "perdían las colonias" 94: los europeos, sobre todo ingleses y franceses, habían intentado "fomentar la riqueza colonial por medio del trabajo libre, dando a los negros libertad absoluta y estímulos [...] para trabajar a jornal en su mejoramiento, y estos, recobrando en la libertad civil la libertad de sus instintos naturales, [habían] abandonado el trabajo y arruinado las colonias donde se [habían] hecho tan desoladores ensayos"95. Y es que los africanos eran naturalmente indisciplinados y si no se les sometía a un rígido régimen de trabajo caían en el ocio y la vagancia. Todo ello conducía a la reducción de la fuerza de trabajo y, por ende, a la ruina de aquellos territorios donde se había suprimido la esclavitud, pues la escasez de trabajadores no podía suplirse con mano de obra europea: esta no estaba acostumbrada a trabajar en un clima tropical y los indios tampoco tenían "la necesaria fortaleza para llenar las obligaciones extrañas a su estado natural"96. Finalmente, remató su argumentación analizando en extenso el caso estadounidense, y concluyó que en el supuesto de que ganase el Norte y sus tesis abolicionistas arruinaría al Sur"97: "otra demostración también general, con exactas apreciaciones, de que la guerra desastrosa que [...] se [mantenía] en la América septentrional [era] debida al giro evidentemente equivocado que [habían] dado las naciones a la cuestión de los negros; queriendo arruinar intereses cuantiosísimos, por causa de algunas palabras mal sonantes" 98.

En similares argumentos incidió el coronel Luis Fernández Golfín, fiel seguidor de Ferrer. Comenzaba citando a Jaime Balmes para afirmar que la abolición de la esclavitud alteraría la propiedad y acarrearía una dislocación social tal que sería muy difícil saber "sus últimas consecuencias"99. Como Ferrer, mantenía que la legislación sobre los esclavos había sido suave y que su bienestar económico era superior al de los proletarios europeos sometidos “a la voluntad de un señor despótico, dueño

91 Ferrer 1864a, p. 181.

92 Ferrer 1864a, p. 185.

93 Ferrer 1864a, p. 188.

94 Ferrer 1864a, p. 94.

95 Ferrer 1864a, p. 192. Afirmó que la abolición en las colonias inglesas había sido su "completa ruina" (p. 134).

96 Ferrer $1864 a$, p. 8.

97 Ferrer 1864a, p. 218.

98 Ferrer 1864a, p. 293.

99 Fdez. Golfín 1866, p. 49. 
del taller o de la fábrica"100. De hecho, se podía decir que la esclavitud en Cuba era de "nombre solamente"101, y que "el sistema disciplinario" de las grandes fincas en América producía "el satisfactorio resultado de que la esclavitud no [constituyese] nunca tropiezo ni embarazo para el verdadero progreso y la libertad, como [sucedía] en Europa con las clases descomodadas ( sic)"102. Y criticando a Saco, consideraba que "los duros trabajos de los ingenios de Cuba sólo [podían] ser ejecutados por brazos

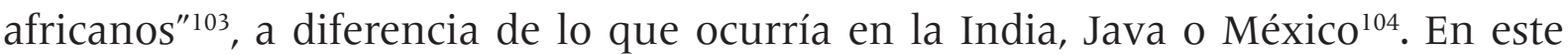
sentido, es evidente que tanto Ferrer como Fernández Golfín estaban familiarizados con la excepción planteada por Smith y desarrollada por McCulloch y Carlyle.

Los abolicionistas que proponían un amplio periodo de transición y la indemnización de los propietarios, como Fermín Figuera, también destacaban la especial adecuación de la mano de obra negra a los trabajos duros y al clima antillano. No obstante, consideraban que dicho condicionamiento se podría superar con el tiempo. Figuera propuso un periodo de transición y unas reformas -que recuerdan a las de Saco y Sagra- con la finalidad de redistribuir la población entre el campo y la ciudad, ennoblecer el trabajo agrícola que estaba envilecido, promocionar la inmigración de negros, chinos y blancos, y cambiar las bases del sistema productivo ( separando el cultivo de la caña del proceso de elaboración del azúcar, intensificando las labores agrarias, utilizando nueva tecnología, etc.). Solo una vez producidos todos estos cambios se podría abolir la esclavitud ${ }^{105}$. Es decir, era necesario un largo periodo de transición en el que introducir mejoras que cambiasen el sistema productivo y posibilitasen la existencia de mano de obra libre y no necesariamente de raza negra.

En el terreno de los partidarios de la abolición gradual también hay que situar a Francisco Armas y Céspedes, quien -desde Cuba- expuso con gran claridad los principales argumentos económicos contra la esclavitud. En De la esclavitud en Cuba (1866) afirmó que la Economía condenaba sin paliativos dicha institución y, en consecuencia, no había verdadero economista que la pudiese defender: "La libertad del trabajo y el poder de producir son ideas absolutamente correlativas. Mientras hay mayor libertad en el individuo, es mucho mayor la producción de éste. Mientras más libre sea el hombre, dará mejores y mayores productos"106. También el capital era menos productivo en las explotaciones esclavistas que estaban mal gestionadas, hasta el punto de que se llegaba a disipar lo invertido en ellas ${ }^{107}$. Concluyó:

La esclavitud ahoga las condiciones de existencia del capital y del trabajo. Deja exhaustas las tierras, porque no ha sabido cultivarlas con inteligencia ni devolverles las fuerzas de que

100 Fdez. Golfín 1866, p. 50.

101 Fdez. Golfín 1866, p. 50.

102 Fdez. Golfín 1866, p. 57.

103 Fdez. Golfín 1866, p. 64.

104 Fdez. Golfín 1866: 62. Dedicó el capítulo quinto a demostrar la superioridad de los africanos por su rendimiento y adaptación a las tierras caribeñas. Citando a Ferrer, señaló los efectos negativos de la abolición inmediata en el caso haitiano (p. 61).

105 Figuera 1866., p. 7-8.

106 Armas 1866, p. 183.

107 Armas 1866, p. 211. 
las ha privado. Acarrea pobreza general, hipotecas, censos y ruinas, porque se ha gastado, por todos conceptos, más de lo conveniente, y porque no se ha obtenido toda la producción competente. Y viene, al fin, a demostrar, de una manera incontestable, que una vida de indolencia y deudas ha de ser, y es, muy inferior a una vida de industria e independencia ${ }^{108}$.

Armas no aceptó la excepcionalidad de la esclavitud para los países tropicales. Es más, mantuvo que si se hubiera optado por otra forma de explotación la riqueza hubiera crecido de forma más progresiva pero también más sólida ${ }^{109}$. En el capítulo XIX de su libro realizó un análisis de la industria azucarera cubana, basándose entre otras fuentes en las cifras del hacendado Juan Poey ${ }^{110}$. Su conclusión fue que los ingenios azucareros explotados bajo un régimen esclavista eran ruinosos:

Los provechos del cultivo del azúcar son en extremo bajos. Si esa industria no se ha abandonado ya, es porque una gran cantidad de capital fijo existe convertido en formas inútiles para otro objeto, siendo preciso principiar por destruir el capital para verificar un cambio. Y si todavía se fomentan nuevos ingenios, es porque muchos suelen entrar incautamente en una empresa riesgosa, esperanzados de verse tan favorecidos de la fortuna como unos pocos lo fueron, sobre todo en terrenos nuevos, que con corto trabajo dan cosechas abundantes ${ }^{111}$.

En suma, se equivocaban "considerablemente los que [suponían] rica, próspera y feliz a la isla de Cuba bajo el sistema en que [allí estaba] organizado el trabajo"112. Además, la producción azucarera cubana, en comparación con la de las colonias inglesas y francesas, era ya entonces (1866) considerablemente inferior ${ }^{113}$. No obstante, la experiencia de dichas colonias le llevó a defender la abolición gradual en las españolas:

Con motivo de la emancipación, la producción del azúcar disminuyó en más de un tercio en las colonias británicas, así como en las francesas; y en las unas y en las otras aquella medida fue una operación desastrosa, económicamente considerada. Arrancó brazos al cultivo, disminuyó la producción, desorganizó la industria, y asestó un tiro de terribles consecuencias contra la riqueza pública. En vano ensayaron los propietarios distintos medios de remediar el daño $0^{114}$.

Era necesario por tanto un periodo de transición para preparar y educar a los esclavos negros para la libertad, "infundiéndoles industria,estímulo ylaboriosidad"115, y mejorando sus condiciones de trabajo.

\section{La Escuela Economista: librecambio y abolición inmediata}

Aunque muchos autores criticaron las tesis de Ferrer o las más moderadas de los abolicionistas gradualistas, fueron los autores de la Escuela Economista -con la

108 Armas 1866, p. 221.

109 Armas 1866, p. 228.

110 Armas 1866, p. 233.

111 Armas 1866, p. 258.

112 Armas 1866, p. 258.

113 Armas 1866, p. 260.

114 Armas 1866, p. 270-1.

115 Armas 1866, p. 351. 
ayuda de Labra- los que argumentaron con mayor coherencia a favor de la abolición inmediata, rechazando la supuesta excepcionalidad del trabajo esclavo en las economías antillanas ${ }^{116}$. Si bien los miembros de la Escuela Economista utilizaron argumentos económicos muy similares a los de Armas para sustentar la abolición de la esclavitud, los primeros señalaron que la abolición en las colonias francesas e inglesas y en los Estados Unidos había sido positiva, y por eso era innecesario un periodo de transición como el que proponía el autor cubano.

El grupo de economistas liberales que comenzaron a manifestar sus opiniones a partir de los años cincuenta del siglo XIX, constituido -entre otros-por Luis María Pastor, Manuel Colmeiro, Laureano Figuerola, Gabriel Rodríguez, José Echegaray, Segismundo Moret, José María Sanromá y los hermanos Félix y Juan Eloy Bona, ha pasado a la historia con el nombre de Escuela Economista. Defendieron un Estado mínimo, el librecambismo, la baja presión fiscal, el control del gasto público, el equilibrio presupuestario, el libre funcionamiento del mercado y, por supuesto, la abolición de la esclavitud.

Más que teóricos, fueron divulgadores de los principios liberales en diferentes ámbitos académicos, periodísticos y políticos, y participaron en diversos foros de debate tales como la Sociedad de Economía Política, la Asociación para la Reforma de los Aranceles de Aduana, la Real Academia de Ciencias Morales y Políticas, el Ateneo de Madrid y la Sociedad Abolicionista. Durante el Sexenio contribuyeron a la aprobación de medidas monetarias, fiscales y arancelarias que supusieron una mayor liberalización de la economía española y su integración en Europa. No obstante, cabe destacar que cuando ocuparon cargos públicos fueron muy pragmáticos: propusieron algunas medidas que estaban directamente en contra de sus propios principios (como el monopolio de emisión concedido al Banco de España por Echegaray y el arancel proteccionista de 1906 aprobado por el gabinete Moret), o bien hicieron concesiones que edulcoraban sus ideas más radicales (como el arancel Figuerola de 1869, que conducía gradualmente al librecambio, y la ley Moret de 1870, que renunciaba a la abolición inmediata de la esclavitud).

Sus fuentes de pensamiento fueron variadas, desde economistas británicos como Smith y sus discípulos de la Escuela Clásica, hasta españoles como Álvaro Flórez Estrada, pero sobre todo se debe destacar al propagandista inglés Richard Cobden y al francés Frédéric Bastiat. Es decir, sus vínculos con la escuela optimista francesa y sus medios de difusión, el Journal des Économistes y la Sociéte d'Économique Politique, fueron muy fuertes. Dada la importancia que otorgaron a Bastiat, sus principales obras se tradujeron al español y se reeditaron a menudo: Sofismas económicos (1846, 1847, 1848, 1853, 1854 y 1859), Cobden y la Liga o la agitación inglesa a favor de la libertad de comercio ( 1847 y 1865), y Armonías económicas (1858, 1859, 1870 y 1880$)^{117}$.

116 Hernández Iglesias 1866, p. 30, respondió a Ferrer y admitió que cuando se aboliese la esclavitud Cuba se resentiría, pero se recuperaría pronto gracias a la reforma arancelaria y educativa.

117 Sobre las fuentes de pensamiento de los miembros de la Escuela Economista se puede acudir a las Lecciones de Economía Política de Pastor (1868, caps. XI a XVI) o a las memorias de Sanromá. Éste cuenta que su maestro Figuerola le hizo estudiar las Armonías económicas de Bastiat (Sanromá 1887- 
Bastiat (1801-1850) había sido desde joven lector de Smith y Say, pero sobre todo de Charles Comte y su Tratado de legislación (1827). Sus ideas se sustentaban en una hipótesis sencilla -"los intereses, dejados a sí mismos, tienden a formar combinaciones armónicas"118 - y en el principio de la libertad, irreconciliable con cualquier forma de coacción"119 - "la sociedad tiene como elemento al hombre, que es una fuerza $l i b r e^{\prime \prime 20}$. No obstante, había individuos que utilizaban la coacción y el engaño para vivir a costa de los demás. En tal caso se incluían las guerras, las opresiones sacerdotales, los fraudes industriales, los monopolios y -por supuestola esclavitud, que "exigía de un hombre todos los servicios que se le puedan arrancar a la fuerza, sin devolverle nada a cambio"121.

Bastiat unió asimismo abolicionismo y librecambio, como luego harían también sus discípulos españoles de la Escuela Economista. En un libro que tuvo mucha difusión en España, Cobden y la Liga, cuya primera traducción de 1847 se realizó justo un año después del viaje del propio Cobden por la Península, Bastiat realizó una historia de la Liga inglesa a favor de la libertad comercial a través de una antología de las intervenciones de sus principales miembros en diversos mítines propagandísticos. Pero también abordó el tema de la esclavitud y planteó una duda importante: ¿Se debía limitar la importación de determinados bienes -como el azúcar- elaborados con mano de obra esclava en Brasil o en las Antillas españolas? ¿Proponer la libertad de comercio en este caso no sería perpetuar la esclavitud? En la introducción, Bastiat señaló que los productores azucareros de las colonias inglesas reclamaban trabas a la introducción de azúcar extranjero, y acudió a la autoridad de su admirado Comte para documentarse sobre dicha producción en régimen de trabajo esclavista ${ }^{122}$. En ningún momento -al igual que Comte- mantuvo que la esclavitud se pudiese justificar en tierras antillanas, y además reprodujo un discurso de Cobden -pronunciado en una reunión de la Liga del 1 de mayo de 1844-en el que éste defendía abrir el mercado inglés a los productos coloniales extranjeros y rebatía la nueva argucia de los proteccionistas que querían defender sus intereses acudiendo paradójicamente a argumentos humanitarios (como el de la no perpetuación de la esclavitud). Para el economista inglés siempre sería prioritaria la abolición de la esclavitud por encima de la libertad comercial si esta condujese a perpetuar la esclavitud, pero afortunadamente ambas causas estaban en el mismo bando. En primer lugar, Cobden señalaba:

siempre he profesado la opinión de los célebres escritores que se han ocupado de esta materia, los Smith, los Burke, los Franklin, los Hume, grandes pensadores

1894, I, p. 88), pero también realizó una profunda lectura de los grandes economistas europeos como Smith, Malthus, Ricardo, McCulloch, James y John Stuart Mill, Say y Droz, y de españoles como Flórez de Estrada (Sanromá 1887-1894, II, p. 296).

118 Bastiat 2004, p. 34.

119 Bastiat 2004, p. 43.

120 Bastiat 2004, p. 39

121 Bastiat 2004, p. 268

122 Bastiat 1847, p. LIX. 
del siglo, siempre he creído que el trabajo esclavo es más costoso que el trabajo libre, y que abandonándolos a la concurrencia el último destruiría al primero ${ }^{123}$.

Y a continuación aseveraba que no permitir la entrada del azúcar "manchado por la esclavitud" no sólo perjudicaría al consumidor inglés, que pagaría unos elevados precios por el mismo, sino que al restringirse la concurrencia se invalidaría uno de los medios más eficaces para vencer a la esclavitud:

Sostenemos con los abolicionistas (anti-slavery-convention) que el trabajo libre puesto en concurrencia con el trabajo esclavo será menos caro al paso que más productivo, y que al fin le vencerá haciendo oneroso para el plantador el horrible sistema de mantener a sus hermanos en servidumbre ${ }^{124}$.

Por tanto, las Antillas no eran un caso excepcional en cuanto a la posible rentabilidad del trabajo esclavo, y la mejor prueba de ello era que cuando el trabajo esclavo se sometía a la competencia del libre peligraba la viabilidad económica del primero.

De esta fuente intelectual (Cobden-Bastiat) fue de la que principalmente bebieron los miembros de la Escuela Economista. Los economistas españoles abolicionistas desarrollaron sus argumentos a lo largo de la década los sesenta, quedando sintetizados en las conferencias que pronunciaron Félix Bona (18211899), Gabriel Rodríguez y Joaquín María Sanromá en el acto organizado por la Sociedad Abolicionista en el Teatro Lope de Rueda de Madrid en 1872. Ellos y otros oradores emplearon diversos argumentos de tipo religioso, filosófico, político y jurídico, pero como apuntó el pedagogo e historiador Fernando de Castro, que presidía en aquel momento la Sociedad, todos tuvieron en cuenta también los argumentos económicos, sosteniendo que la abolición no sólo no había "paralizado el trabajo", sino que lo había tornado "mejor y más barato"125. Los tres economistas, en la línea de Bastiat, hicieron una exaltación de la libertad y del papel que desempeñaba la misma para explicar la prosperidad económica. La libertad, según Bona, era "la más indispensable condición de todo progreso, y la única y segura base de engrandecimiento y de riqueza que existe en las sociedades humanas"126. Y apuntillaba: "La libertad trae el máximum de civilización, de orden, de actividad y de poder a los pueblos, y por eso hoy los más ilustrados, ricos y poderosos de la tierra son Inglaterra y los Estados Unidos, que son los que mayor suma gozan de libertad" ${ }^{127}$. Precisamente, para mostrar que la libertad de trabajo no había perjudicado a la riqueza de estos dos prósperos países y de sus colonias, Bona se centró en la experiencia abolicionista inglesa y Rodríguez en la estadounidense. Es decir, ambos

123 Bastiat 1847, p. 259-60.

124 Bastiat 1847, p. 260.

125 VV. AA. 1872, p. 9.

126 VV.AA. 1872, p. 18. Pastor 1868, p. 61, sostuvo que las condiciones para el perfecto desarrollo del trabajo eran la justicia, la seguridad y, en primerísimo lugar, la libertad, pues sin ella era "imposible el ejercicio de las facultades humanas" y el aumento de la riqueza.

127 VV. AA. 1872, p. 38-9. 
ilustraron la tesis smithiana -suscrita también por Bastiat- que mantenía que el trabajo libre era más barato y productivo. Y Sanromá dio un paso más, mostrando los efectos beneficiosos de la libertad en todos los casos, es decir, generalizando la tesis smithiana incluso para la economía cubana y sin contemplar por tanto ninguna excepción: la libertad -en la línea de Bastiat- sólo podría conllevar prosperidad en todo el planeta. Pasemos ahora a analizar los tres casos destacados por los citados economistas.

Bona se mostró muy firme al criticar las tesis de los esclavistas que sostenían que la libertad de trabajo había ocasionado la decadencia del comercio y la riqueza de Jamaica $^{128}$. La decadencia en esta isla no se debía a la abolición de la esclavitud, sino al comportamiento de los propietarios de esclavos que no supieron sacar partido de la nueva situación y, sobre todo, de la docilidad de los africanos una vez liberados ${ }^{129}$. Contrapuso el caso de Jamaica al de Antigua, en donde los propietarios supieron incentivar a los africanos optando por la manumisión inmediata; en consecuencia, esta última isla "exportó más azúcar y frutos de su industria agrícola"130. Es más, no sólo las cifras de exportación de azúcar de la Antigua, sino también las de Barbados, Dominica, San Cristóbal, Santa Lucía y Trinidad mostraban un aumento después de la abolición inmediata de la esclavitud. Reiteró que los datos de exportación de azúcar en el resto de las islas, entre las que destacaba otra vez Jamaica, no eran tan favorables debido "a la falta de tacto y habilidad de los propietarios, o a otras causas de fuerza mayor" que no habían tenido que ver con la abolición ${ }^{131}$. Los dos comportamientos dispares representados por Jamaica y Antigua mostraban "que las crisis producidas por el tránsito del trabajo esclavo al trabajo libre se dominan[aban] y evita[ban] con la manumisión repentina y no [podían] evitarse con la gradual"132. Precisamente en esta diferencia profundizaría luego Labra en su amplísima obra sobre la esclavitud, como se expondrá en el próximo epígrafe, estableciendo un paralelismo entre Cuba y Jamaica, por una parte, y Puerto Rico y Antigua, por otra ${ }^{133}$.

Rodríguez confirmó los efectos positivos del trabajo libre en el caso estadounidense. A pesar de que esta economía estaba en el peor de los escenarios tras el conflicto bélico - con el capital físico y humano destruido y el Estado aquejado de considerables problemas financieros- la producción, gracias al trabajo libre, había renacido "casi instantáneamente, y en los pocos años transcurridos desde 1866 ha[bía] llegado a superar los resultados de la época anterior a la guerra, o sea de 1850 a 1860, en casi todos los artículos de grande importancia"134. Incluso en el caso de la producción azucarera, que se había visto dañada por el desbordamiento de los ríos Misisipi y Colorado y el mal estado de los diques afectados por la guerra, sus

128 VV. AA. 1872, p. 28.

129 VV. AA. 1872, p. 34.

130 VV. AA. 1872, p. 36.

131 VV. AA. 1872, p. 37.

132 VV. AA. 1872, p. 38.

133 Labra 1872, p. 15-25.

134 Rodríguez 1872, p. 28-9. 
resultados manifestaban las ventajas del trabajo libre, "siendo mayor la producción en relación con el área cultivada y el número de trabajadores empleados"135.

Sanromá -que como se ha apuntado estuvo al tanto del pensamiento de Smith, McCulloch, Mill y, sobre todo, Bastiat- trató el caso de Cuba que era sin duda el más espinoso. Años más tarde, cuando ya había quedado abolida la esclavitud en esa isla, dijo que tuvo que enfrentarse a la siguiente tesis esclavista: "El azúcar y el tabaco, ¿cómo se producirían sin los negros y sin el prudente correctivo del fuete? Axiomático: sin esclavos negros, adiós Cuba, adiós Puerto Rico, adiós tierras, adiós cosechas, adiós ingenios"136. No obstante, afirmó que había tenido a su alcance la fuerza de los argumentos de la escuela economista liberal europea, que había logrado tres grandes éxitos: la libertad de comercio, la limitación de las guerras y, en primerísimo lugar, "la abolición de la esclavitud en las colonias inglesas y francesas; preparando la más difícil, que se obtuvo después, en los Estados Unidos, y la que llamaban imposible en el Brasil y Posesiones españolas"137.

Sanromá -en aquel momento diputado a Cortes por la provincia de Puerto Rico y vicepresidente de la Sociedad Abolicionista - inició su discurso diciendo que la esclavitud era un problema que, sobre una población de 1.600 .000 habitantes, afectaba a unos 600.000 esclavos, incluyendo los ilegales introducidos en Cuba a pesar de la prohibición de la trata ${ }^{138}$. No se podía aducir a favor de esta institución que se hubiera suavizado por las leyes de Indias, la influencia del catolicismo o el derecho concedido a los esclavos de contraer matrimonio y adquirir un peculio e incluso su libertad ${ }^{139}$. La "pretendida felicidad" del esclavo no era más que una ironía que "chorreaba" sangre ${ }^{140}$. A las niñas negras se las prostituía, los esclavos trabajaban jornadas de dieciséis horas en los ingenios, su vestimenta era mugrienta y su comida nefasta, y la tortura estaba al orden día. En cambio, en un país con instituciones libres el jornalero tenía "en sí mismo y en el auxilio de las demás clases infinidad de medios y recursos para mejorar su condición y regenerarse", y nunca cambiaría su situación por la de un esclavo ${ }^{141}$. Para disipar cualquier duda apeló a la estadística: la mortalidad era mayor en los países esclavistas ${ }^{142}$. Es decir, fue muy crítico con todos los tópicos defendidos por los esclavistas y que había sintetizado con claridad Ferrer.

Sanromá construyó su discurso dando gran importancia a los argumentos económicos y afirmando que "Cuba no ha[bía] prosperado por la esclavitud, sino a pesar de la esclavitud"143. No se podía negar su riqueza en productos como plátano, piña, tabaco, caoba, café, azúcar y cobre, aunque sin olvidar que también se había beneficiado de los infortunios de otras islas del Caribe y algunas repúblicas

135 Rodríguez 1872, p. 30.

136 Sanromá 1887-94, II, p. 345.

137 Sanromá 1887-94, II, p. 296.

138 Sanromá 1872, p. 9.

139 Sanromá 1872, p. 10.

140 Sanromá 1872, p. 10.

141 Sanromá 1872, p. 11.

142 Sanromá 1872, p. 12.

143 Sanromá 1872, p. 4. 
sudamericanas. No obstante, si había un secreto de su prosperidad radicaba en la "libertad de industria" -que había permitido establecerse en la isla "al extranjero industrioso"144 - y en la "suavidad" del nuevo régimen político y administrativo tras $1868^{145}$.

Por tanto, sin negar la prosperidad de Cuba y los avances que se habían producido recientemente, no había que exagerar su riqueza.

Cuba podría mantener una población de diez a veinte millones de habitantes y no tenía más de millón y medio ${ }^{146}$. Sólo se cultivaba una décima parte del territorio cubano y, lo que era más grave, los 1.500 ingenios de azúcar existentes "apenas produc[ían] más de un promedio de 39 toneladas por ingenio: labores para las cuales bastarían 74 operarios, llega[ban] a emplear hasta 143", lo que era indicativo de la baja productividad del trabajo esclavo que ya señalaran Smith y sus discípulos. Asimismo, la renta media anual de un ingenio azucarero apenas llegaba al 5\% en el mejor de los $\operatorname{casos}^{147}$, pero había que tener en cuenta las pérdidas en las que incurrían otros muchos y que mermaban el capital de esas explotaciones. En suma,

Si el promedio de la producción es escaso, si es baja la renta, si el capital se va debilitando, es porque la esclavitud va retardando la aplicación de poderosos mecanismos, es porque las bajas y el valor siempre creciente de la carne negra imponen diariamente a la propiedad desembolsos cada vez más considerables, y aumentan estos desembolsos con el cultivo meramente extensivo, tan propio de aquellos pueblos que no conocen otra organización del trabajo que la servil ${ }^{148}$.

La esclavitud era una plaga que todo lo arrasaba: "población, capital, propiedad, religión, sentimientos morales, instintos políticos"149. Es más, como también mantuvo Comte, en Cuba se había "deshonrado y envilecido el trabajo manual" y se había "aclimatado el trabajo lánguido, perezoso, que no [obedecía] al impulso del interés individual, sino que se [movía] al compás de los latigazos y a la presión del cepo"150. Pero Bona no sólo consideró el trabajo esclavo más costoso y menos productivo, sino que llevando hasta sus últimas consecuencias la tesis smithiana y haciendo un contrafactual de lo que podría haber crecido la producción bajo un régimen de libertad, afirmó que dicho régimen hubiera promovido más la prosperidad cubana. No cabía por tanto la posibilidad de la supuesta excepcionalidad planteada por el propio Smith y desarrollada por McCulloch.

Por último, hay que destacar que los tres economistas -Bona, Rodríguez y Sanromá- unieron sus tesis a favor de la abolición a la defensa de reformas

144 Sanromá 1872, p. 4.

145 Sanromá 1872, p. 5.

146 Sanromá 1872, p. 12-3.

147 Sanromá 1872, p. 12.

148 Sanromá 1872, p. 14.

149 Sanromá 1872, p.14.

150 Sanromá 1972, p. 13-4. Mantuvo que la situación de Cuba era más compleja que la de Puerto Rico debido -entre otras cosas- a los numerosos esclavos africanos que se introdujeron ilegalmente después de la prohibición de la trata, la cuestión de los africanos emancipados, o la población china que estaba casi sometida a un régimen de esclavitud. 
administrativas y políticas en Puerto Rico y Cuba y al librecambismo. Este -como había apuntado Bastiat-ayudaba a disolver la institu ción del esclavismo y, en general, todas las situaciones privilegiadas. Así lo sintetizaba Sanromá: "los reformistas somos los legítimos representantes del principio de integridad, porque queremos una sola e idéntica España para aquende y allende los mares, sin dictaduras, sin monopolios y sin esclavos"151.

\section{Tercera etapa (1870-1886): el triunfo del abolicionismo}

Esta etapa fue la más combativa y se inició una vez aprobada la ley Moret en 1870. La norma defraudó a los abolicionistas por ser una ley preparatoria que no erradicada inmediatamente la esclavitud y porque -según se denunció persistentemente- no se aplicaba en la práctica, sobre todo en Cuba ${ }^{152}$. Tampoco gustó a los esclavistas, que querían alargar lo máximo posible el periodo transitorio ${ }^{153}$. Los argumentos de ambos bandos estaban ya perfilados desde la etapa anterior, y su tarea se centró ahora principalmente en difundirlos.

\section{La Liga Nacional: esclavismo y proteccionismo en Manzanedo y Güell}

Aunque acabasen ganando, la recta final del debate no les resultó fácil a los abolicionistas, pues los esclavistas se organizaron para defender sus intereses tras la aprobación de la Ley Moret y los primeros intentos de abolir inmediatamente la esclavitud en Puerto Rico. Se reunieron en torno al Casino español de La Habana, que se creó en 1870, de donde surgió el Centro Hispano-Ultramarino de Madrid en 1871, al que siguieron otros centros ubicados en Barcelona (a iniciativa de la patronal Fomento de la Producción Nacional), Málaga, Santander, Valencia, Palma, Cáceres, Ampuero, Sevilla, Cádiz, Avilés, Bilbao y Zaragoza ${ }^{154}$. Finalmente, de estos centros nació en 1873 la Liga Nacional con la finalidad de mantener la integridad del territorio nacional ${ }^{155}$. La Liga tuvo un éxito espectacular en Barcelona, y a ella se sumaron industriales y comerciantes proteccionistas como Antonio López y López -marqués de Comillas-, José Ferrer y Vidal, o Juan Güell y Ferrer, entre los que además había vínculos empresariales y familiares.

La fuerza de la argumentación económica empleada para defender la esclavitud radicó en lograr unir los intereses esclavistas y proteccionistas ${ }^{156}$. Ambas partes coincidieron además en proponer la utilización de la fuerza para reprimir cualquier

151 Sanromá 1872, p. 21.

152 Sanromá 1872, p. 12.

153 La opinión de aquellos próximos al ministerio de Ultramar estuvo a favor de la abolición gradual. Este fue el caso de José Ahumada y Centurión (1810-1882), que utilizó argumentos muy conocidos: en las colonias intertropicales la raza más fuerte y que mejor se adaptaba al territorio era la negra, la nefasta experiencia de las colonias europeas tras la abolición y "la necesidad de asegurar la continuación del trabajo agrícola, base principal de la riqueza de las colonias" (Ahumada 1870, p. 169-73). También realizó una reflexión sobre la abolición citando a Saco (Ahumada 1874, p. 492). 154 Manzanedo 1872b, p. 12.

155 Manzanedo 1873, p. 23.

156 Sobre este tema véanse Maluquer 1971 y Schmidt-Nowara 1998. Una síntesis de los argumentos proteccionistas de los economistas catalanes en Perdices y Reeder 2003, p. 168-71. 
sublevación, y emplearon una retórica basada en la defensa de los intereses nacionales amenazados supuestamente por las potencias extranjeras y por algunos sectores de la opinión pública española, principalmente por los "filibusteros" librecambistas y abolicionistas. En sus propias palabras: "Formamos, pues, la conspiración más santa: conspiramos por el bien de España"157. Esta unión de esclavismo y proteccionismo se puede personificar e ilustrar en dos indianos que hicieron fortuna en Cuba: el responsable del Centro Hispano-Ultramarino de Madrid Juan Manuel Manzanedo (1803-1882), que había amasado su riqueza como comerciante, prestamista, armador y negrero; y Juan Güell y Ferrer (1800-1872), comerciante con intereses en las Antillas, líder de los proteccionistas catalanes e impulsor del Centro HispanoAmericano en Barcelona.

Manzanedo, en una memoria presentada en el Centro Hispano-Ultramarino de Madrid el 10 de octubre de 1872, sintetizó los argumentos que sustentaban la necesidad de medidas proteccionistas en el ámbito comercial y de un periodo de transición hacia la abolición, sin especificar su duración:

Cuba y Puerto Rico, gracias a un gobierno de "paternal solicitud", basado en un "sistema de protección a la industria y al trabajo" (que en ningún momento se calificaba de esclavista), se habían convertido en las posesiones más "productivas y valiosas del mundo conocido"158. Los esclavos africanos no estaban preparados para un régimen de libertad de trabajo debido a su naturaleza: "la ignorancia de esas razas que hoy están en dependencia; su absoluta carencia de elementos para subsistir, y mil otras causas [...] prescriben que esta emancipación sea lenta"159. Por lo que la abolición sería "fatal", tanto para la seguridad de las colonias, como para el comercio y la industria española ${ }^{160}$.

La protección de la industria nacional con la finalidad de convertir "a nuestras tierras de Ultramar en lo que deben ser, mercados propios, y no de consumo preferente para las producciones extranjeras"161.

Güell, en la misma línea que Manzanedo, publicó en 1871 La Rebelión cubana contra la independencia de Cuba, en la que intencionadamente introdujo en el mismo saco prácticamente a los independentistas cubanos, a los "economistas cosmopolitas" favorables al librecambio, y a los reformadores surgidos tras la Gloriosa de $1868^{162}$. No hizo ninguna referencia a la esclavitud, sino al "sistema económico" cubano que querían modificar los economistas librecambistas y que había proporcionado un gran progreso a la isla y era "hoy día el más productor, y el que alimenta[ba] un mayor comercio"163. Las medidas de dichos reformadores, entre las que se incluían la supresión de los proteccionistas derechos diferenciales de bandera, conseguirían

157 Manzanedo 1872a, p. 5.

158 Manzanedo 1872a, p. 10.

159 Manzanedo 1872a, p. 21.

160 Manzanedo 1872a, p. 21-2.

161 Manzanedo 1872a, p. 24.

162 Con anterioridad, Güell había criticado duramente a los economistas librecambistas en Refutación de los discursos pronunciados por el Excmo. Sr. D. Luis M. Pastor y otros oradores en varias sesiones de la Asociación para la Reforma de Aranceles (1861) y en Examen actual de la crisis (1867).

163 Güell 1871, p. 33. 
la destrucción de la marina mercante española y de "todos nuestros elementos de trabajo y producción"164. Frente a ellas, Güell defendía las políticas proteccionistas, porque las colonias "facilita[ban] el desagüe de nuestros productos" 165 , y la rica isla de Cuba -en particular- era "el principal mercado exterior de nuestros productos agrícolas y tal vez industriales"166.

\section{Labra y los economistas}

Los miembros de la Escuela Economista continuaron defendiendo su reforma integral para Cuba y Puerto Rico, sustentada en el abolicionismo de la esclavitud, el librecambio y las reformas políticas y administrativas. Su labor en la Sociedad Abolicionista y en su órgano de difusión-El Abolicionista-siguió siendo fundamental, aunque la Sociedad se vanagloriara de actuar al margen de cualquier escuela. Como reiteró Rodríguez en 1875 citando a Bastiat y Cobden, la ciencia económica había concluido que la libertad era el fundamento del sistema económico y la prosperidad, y por tanto la labor del economista era denunciar cualquier restricción a dicha libertad, incluida la esclavitud ${ }^{167}$. Aunque los miembros de la Escuela Economista se mantuvieron firmes en la defensa de una abolición inmediata sin proceso de transición, se propusieron perjudicar lo menos posible a los intereses creados con el fin de reducir al mínimo los posibles obstáculos. Por ello, de mala gana, se mostraron dispuestos a admitir la indemnización a los dueños de esclavos ${ }^{168}$.

En esta tercera etapa se puede apreciar especialmente la colaboración de los miembros de la Escuela con un autor que había estado en la Sociedad Abolicionista desde su fundación, y que con sus estudios aportó más evidencias de las ventajas del trabajo libre. Nos referimos a Rafael María de Labra, abogado, historiador y político nacido en La Habana, que llegó a ser diputado por Puerto Rico y senador, presidente de la Sociedad Abolicionista (1876-1888), miembro de la Real Academia de Ciencias Morales y Políticas, y uno de los fundadores de la Institución Libre de Enseñanza. Fue asimismo autor de numerosas obras sobre América y la cuestión social ${ }^{169}$, y en particular sobre la abolición de la esclavitud. De sus numerosas publicaciones destacan La abolición de la esclavitud en el orden económico (1874) y La brutalidad de los negros (1876).

En este último ensayo mostró, con cifras y acudiendo a la experiencia en las colonias españolas y del resto de Europa, que la condición natural de la raza negra no justificaba su esclavitud. En particular, no se sustentaba la supuesta "indolencia",

164 Güell 1871, p. 28.

165 Güell 1871, p. 5.

166 Güell 1871, p. 36.

167 Rodríguez 1875, p. 7.

168 Una síntesis sobre las indemnizaciones en Labra 1869, p. 13-5.

169 Labra entró en contacto con los miembros de la Escuela Economista en la Universidad Central de Madrid desde 1858, y colaboró con ellos en diversas revistas (Acebrón 2006, p. 29, 33, 297). Entre sus fuentes de pensamiento se incluían obras de los miembros de la Escuela Economista, como Colmeiro, y de Augustin Cochin, miembro de la escuela católica francesa (Labra 1873a, p. 387-456; 1869, p. 2). 
"aversión al trabajo", "ferocidad de instintos", e "incapacidad, casi absoluta, para recibir toda cultura social" de los esclavos negros ${ }^{170}$. Su supuesta aversión al trabajo se debía a que a nadie le gustaba "sudar gratuitamente en provecho de otros"171. Es decir, la libertad y el incentivo del interés propio, como mantuvieron Bastiat y sus discípulos españoles, eran necesarios para estimular al trabajador. Es más, "la esclavitud no solo [esterilizaba] los campos, [deshacía] los capitales y [aniquilaba] al trabajador esclavo, sino que [deshonraba] el trabajo y [hacía] más o menos imposibles, pero siempre difíciles, la robusta existencia, los hábitos de laboriosidad, el celo y la energía del hombre"172. En definitiva, la situación del esclavo era, como también apuntó Comte, “una condición externa que rebaja[ba] y corromp[ía] a todo individuo, de cualquier raza que [fuera]"173.

La abolición de la esclavitud en el orden económico desempeñó un lugar relevante en el debate abolicionista, precisamente por centrarse en los argumentos económicos. Desde las primeras páginas exponía la tesis smithiana contraria a la esclavitud: "la superioridad del trabajo libre" estaba "de un lado, en la economía de brazos y de medios que [suponía], y de otra parte, y sobre todo, en el aumento de productos que con él se [obtenía]"174. En particular, el caso cubano era el ejemplo más claro de la inferioridad del trabajo esclavo respecto al libre. Así, después de suministrar unas cifras de producción azucarera de Cuba que eran considerablemente menores que las de Jamaica y Barbados, concluía que la causa del atraso de Cuba residía en "los gastos que ocasiona[ba] una negrada sobrada crecida, en los despilfarros de la administración, y en la demasía de terrenos que [era] preciso tener por el cultivo extensivo que [era] de rigor en todos los países esclavitas"175. Luego realizaba un extenso estudió de las consecuencias de la abolición de la esclavitud en las colonias francesas e inglesas, así como en los Estados Unidos, para llegar a las mismas conclusiones:

En las colonias francesas se había abolido la esclavitud en 1794, la había restablecido Napoleón en 1802, y se había abolido definitivamente en 1848. El caso francés ilustraba los efectos favorables del trabajo libre desde el año 1857, una vez vencidas muchas contrariedades iniciales y "a pesar del régimen mercantil que aun subsistía". A partir de 1849 se redujo el número de hectáreas cultivadas en Martinica, Guadalupe y Guyana, pero la producción aumentó, "lo que demuestra que se trabajó más y mejor que en 1847 y que la agricultura progresó en medios y procedimientos"176.

En las colonias inglesas se había abolido la esclavitud en 1834 y su caso ilustraba perfectamente los defectos que traían las medidas transitorias, tales como el sometimiento de los esclavos a un periodo de aprendizaje durante unos años. Aunque las experiencias habían sido diferentes según las islas, destacaban los dos casos extremos de Jamaica y Antigua: la bajada de producción "fue muy distinta en cada una de las Colonias: considerable hasta lo sorprendente

170 Labra 1876, p. 1.

171 Labra 1876, p. 32.

172 Labra 1876, p. 33-4.

173 Labra 1876, p. 34. La misma argumentación en Labra 1869, p. 54-110, citando a Cochin.

174 Labra 1873a, p. 6.

175 Labra 1873a, p. 7-8. Las cifras de producción azucarera las tomó, como Armas, de un informe del no "muy abolicionista" Juan Poey.

176 Labra 1873a, p. 77. 
en Jamaica, mediana y con oscilaciones en Trinidad, escasa hasta trocarse en alza durante el período de aprendizaje en Barbada, e insignificante para traducirse en seguida en franco y notable progreso en Antigua; graduaciones todas que [respondían] así a la diversidad de las condiciones económicas de cada comarca, cuanto al grado de resistencia que opusieron las colonias inglesas a los dos bills de 1833 y $38^{\prime \prime} 177$.

Comparando el caso inglés y el francés, Labra deducía que la abolición había sido "menos favorable a las colonias inglesas que a las francesas; pues que mientras en aquellas que pasaron por el aprendizaje y luego por la abolición, algunas quedaron atrás tan considerablemente como Jamaica, en éstas, donde la abolición fue repentina y por tanto la sacudida mayor, presentaban todas, diez años después de la emancipación, un progreso a todas luces evidente y edificante"178. Por este motivo los economistas y Labra defendían la abolición inmediata de la esclavitud.

El caso de los Estados Unidos también confirmaba los efectos favorables de la abolición. A pesar del estado de devastación del Sur tras la guerra y de que no había todavía la suficiente perspectiva histórica, la producción de algodón ya era igual que en el tiempo de la esclavitud y se estaba reponiendo la producción de tabaco ${ }^{179}$, y todo ello a pesar de que se utilizaban menos trabajadores, capitales y tierras que en la producción azucarera y tabaquera ${ }^{180}$. Además, Labra subrayó que una de las causas del aumento de la producción de algodón había sido el papel desempeñado por los pequeños cultivadores, lo que a su vez había provocado que la riqueza se distribuyese "por todas las clases, creando por donde quiera sólidos intereses ${ }^{181}$.

Después de analizar estos tres casos, la conclusión de Labra fue que el trabajo libre no había provocado los desastres en la producción que aducían los esclavistas. Y Labra también dio razones particulares para que de una forma inmediata se aboliese la esclavitud en Puerto Rico y Cuba. El caso de Puerto Rico era el más fácil, porque la esclavitud no era allí la base de su sistema económico, pues los esclavos solo suponían un $5 \%$ de la población de la isla ${ }^{182}$ y el cultivo del café y el tabaco se hacía en pequeños lotes de tierra. No obstante,

era preciso utilizar también los argumentos de conveniencia y de interés económico; [...] primero que la abolición inmediata en Puerto-Rico no paralizaría, ni siquiera entorpecería, la producción total del país; segundo, que aun dando por cierto que la emancipación de todos los esclavos de aquella isla [...] perturbase profundamente cierta parte de la producción de la isla, esta no sería la primera producción, representada allí por los frutos menores, por los víveres y artículos de primera necesidad, y no por el azúcar, el café y el tabaco, productos punto menos que exclusivos de los pueblos esclavistas ${ }^{183}$

Sin embargo, Labra creía que los reglamentos dados por las autoridades puertorriqueñas estaban desvirtuando la abolición de la esclavitud, y no entendía qué se quería decir cuando se afirmaba que el trabajo estaba desorganizado. Así lo señalaba en un escrito en el que figuraba como coautor -entre otros- con Gabriel Rodríguez, y en el que se utilizaban argumentos acordes con la crítica de la Escuela Economista al socialismo:

177 Labra 1873a, p. 136.

178 Labra 1873a, p. 137.

179 Labra 1873a, p. 217.

180 Labra 1873a, p. 218.

181 Labra 1873a, p. 218.

182 Labra 1873a: p. 243.

183 Labra 1873b, p. 51. 
¿Es que la autoridad superior de Puerto-Rico profesa la doctrina socialista moderna, harto desautorizada por cierto, conocida en la escuela con el nombre de Organización del trabajo? [...] ¿Es que aquella autoridad piensa, como los capitanes generales de Cataluña y de Andalucía hasta 1860, que el orden público exige la intervención del Estado en la vida industrial para afirmar la sumisión del obrero libre al capitalista y al propietario ${ }^{184}$.

El caso cubano, sin embargo, era más complejo, debido a que había grandes explotaciones en régimen de trabajo esclavo y, por tanto, más esclavos que en Puerto Rico. Pero ello no impedía la abolición inmediata, pues la población africana en Cuba era menor que en las colonias inglesas y francesas, y estas no se habían visto perjudicadas por la abolición. Analizando la historia económica de las Antillas españolas y la favorable influencias que en ellas habían tenido las reformas llevadas a cabo desde el reinado de Carlos III, Labra concluía: "desde fines del siglo XVIII nuestras Antillas vienen preparándose sin interrupción para la transformación del trabajo y la obra de su completa regeneración social; de tal modo, que las disposiciones calificadas de preparatorias en Francia e Inglaterra, y que [a lo sumo] precedieron a los decretos de 1838 y 1848 sólo un par de años, tienen de vida ya en Cuba y Puerto Rico poco menos de medio siglo" ${ }^{185}$. En consecuencia, las colonias españolas estaban en la mejor situación para proceder a la abolición inmediata de la esclavitud ${ }^{186}$.

\section{Conclusión}

Este trabajo ha examinado el papel que desempeñaron los argumentos económicos en el debate sobre la abolición de la esclavitud en las dos últimas colonias españolas del Caribe -Cuba y Puerto Rico-, conectándolos con sus posibles fuentes intelectuales europeas. Dichos argumentos económicos se desarrollaron a la par que los de carácter humanitario, jurídico o político, pero hasta ahora no habían recibido atención. Por otra parte, el citado debate se puede enmarcar en el más general sobre la llamada cuestión social que, una vez conseguida la abolición, pasó a centrarse en el problema obrero, la educación popular y la rehabilitación de la mujer. Es decir, el debate abolicionista no fue más que el primer hito del gran debate sobre la cuestión social que tanto interés iba a despertar en España.

Aunque por motivos diversos, puede afirmarse que entre mediados del siglo XVIII (con Steuart Mirabeau, Du Pont) y finales del XIX (con Cairnes y Fawcett) la esclavitud fue condenada en términos económicos por la gran mayoría de los economistas, ya fueran de la corriente principal o críticos (como Sismondi, Carey o Marx). No obstante, fue Smith quien estableció el eje principal de discusión: el trabajo esclavo -al margen de desincentivar la innovación y representar un obstáculo a la especialización funcional- era más caro y menos productivo que el libre; pero había

184 Rodríguez et al. 1874, p. 80.

185 Labra 1873a, p. 381.

186 En particular, criticó a aquellos abolicionistas que reclamaban un periodo de transición, como Saco (Labra 1869, p. 13-21). Para sus intervenciones parlamentarias contra la esclavitud, véanse Galván 2014 y Hernández y González 1986. 
un excepción importante: la esclavitud era rentable en las plantaciones azucareras y tabaqueras antillanas. En general, hubo un amplio consenso entre los economistas clásicos en que efectivamente el trabajo esclavo era siempre menosroductivo que el libre, quedando algo más abierta la cuestión de su mayor baratura. Sin embargo, también hubo ciertas "disidencias": alguno -como Say- llegó a rechazar de plano inicialmente la tesis smithiana (aunque luego, influido por Comte, terminara aceptándola); otros -como Wakefield o Merivale- afirmaron que la rentabilidad y la eficiencia del trabajo esclavo dependía de las circunstancias (tierra relativamente abundante y mano de obra libre escasa ), o-como Cairnes-distinguieron claramente entre los resultados para los propietarios individuales y para el país en su conjunto; por último, McCulloch desarrolló la idea de la excepcionalidad de la esclavitud en las Antillas -que había apuntado Smith y luego aceptó Mill-, dada la dureza del clima y del trabajo en las plantaciones azucareras, junto a la facilidad para satisfacer las necesidades básicas en el Caribe (argumentos que volvería a esgrimir Carlyle añadiendo consideraciones racistas -como a la natural indolencia de los africanos-y aludiendo a lo sucedido en las posesiones caribeñas británicas tras la emancipación de los esclavos).

Precisamente, en el caso español el debate económico sobre la abolición se centró en buena medida en discutir si Cuba y Puerto Rico representaban o no un caso verdaderamente excepcional. Mientras en los esclavistas se reconocía claramente la línea argumental McCulloch-Carlyle, los abolicionistas siguieron a Bastiat a partir de 1864, quien a su vez se basó esencialmente en el último Say, Charles Comte y Cobden. Sin embargo, los autores españoles raramente citaron directamente sus fuentes intelectuales. Por otra parte, casi todos aludieron a los resultados de la experiencia abolicionista inglesa y francesa en las islas del Caribe para apoyar a conveniencia -en uno u otro sentido-sus propios planteamientos.

Puede considerarse que el debate abolicionista se desarrolló en las tres etapas que definió Gabriel Rodríguez. En la primera ( 1800-1864), Sagra y Saco fueron pioneros en condenar la esclavitud por razones económicas, aunque sus contribuciones quedaron como llamadas de atención aisladas, pues en 1845 aún no se había creado un amplio estado de opinión en torno a la abolición. Sagra atacó la esclavitud porque iba asociada a un modelo productivo -el sistema de plantación azucarera de grandes latifundios- que tenía unas bases muy frágiles y conducía a la deforestación, el monocultivo y la mono-exportación. Saco, por su parte, negó explícitamente que la supuesta excepcionalidad caribeña justificara el empleo de esclavos africanos. Y tanto Saco como Sagra -en la línea smithiana- detallaron los numerosos defectos de la mano de obra esclava, que además era incompatible con una agricultura científica y sofisticada, obligando a un sistema muy simple de cultivo. A la luz de lo ocurrido en las colonias inglesas, abogaron por un proceso de abolición gradual que fuera acompañado de profundas reformas (fomento decidido de la entrada de colonos blancos, sistema de propiedad de pequeñas y medianas parcelas, separación 
del cultivo de la caña de las labores de procesamiento del azúcar, diversificación agrícola, mejora de las infraestructuras de transporte, etc.).

La segunda etapa (1864-1870) arrancó con la constitución de la Sociedad Abolicionista, que marcó el comienzo del debate en sí. Entre los esclavistas puros el más importante fue Ferrer de Couto, que desde Nueva York desarrolló con claridad una línea argumental similar a la de Carlyle -a quien muy probablemente había leído- haciendo uso de medidos eufemismos. Entre los abolicionistas gradualistas destacó Armas y Céspedes, que, pese a aceptar plenamente los argumentos smithianos y negar la excepcionalidad caribeña, consideraba necesario un amplio periodo de transición a la luz de lo sucedido en las colonias inglesas y francesas. Finalmente, los partidarios de la abolición inmediata fueron los economistas liberales de la Escuela Economista seguidores de la escuela optimista francesa, que -frente a la idea del "azúcar manchado por la esclavitud" - afirmaron la compatibilidad de librecambio y abolición; además, Bona, Rodríguez y Sanromá analizaron -respectivamente y en detalle- los casos de las colonias británicas, el sur de Estados Unidos y Cuba, para mostrar la conveniencia económica de una emancipación inmediata de los esclavos.

La tercera etapa (1870-1886), del triunfo definitivo de los abolicionistas, se inició con la ley preparatoria de Moret, que no contentó a nadie. Los argumentos económicos esenciales de los bandos ya estaban perfilados desde la etapa anterior y ahora la labor fue sobre todo de difusión. Los esclavistas -entre los que destacaron Manzanedo y Güell- se organizaron para defender sus intereses uniéndolos a los de los proteccionistas y dándoles un marcado color patriótico; optaron por reclamar un periodo de transición de duración indefinida como mal menor. Entre los abolicionistas radicales -que aceptaron de mala gana la indemnización a los propietarios para acelerar el proceso- brilló especialmente Labra, que reiteró otra vez los conocidos argumentos smithianos y volvió a servirse de los ejemplos estadounidense, británico y francés para apuntalarlos con datos y hechos concretos.

\section{Bibliografía}

AGUILERA, J.M. La formación de la identidad cubana (el debate Saco-Sagra). Madrid: CSIC, 2005.

AHUMADA Y CENTURIÓN, J. La abolición de la esclavitud en países de colonización europea. Madrid: Imprenta de F. López Vizcaíno, 1870.

AHUMADA Y CENTURIÓN, J. Memoria histórica politica de la isla de Cuba, redactada de orden del Señor Ministro de Ultramar. La Habana: Imprenta de A. Pego, 1874.

ARMAS Y CÉSPEDES, F. De la esclavitud en Cuba. Madrid: Establecimiento Tipográfico de T. Fortanet, 1866.

ARROYO, P. La Sociedad Abolicionista Española, 1864-1886. Cuadernos de Historia Moderna y Contemporánea, 1982, n 3, p. 127-150.

BASTIAT, F. Cobden y la Liga o la agitación inglesa a favor de la libertad de comercio. Madrid: Imprenta de Baltasar González, 1847.

BASTIAT, F. Obras escogidas. Madrid: Unión Editorial, 2004. 
BERQUIST, E. Early Anti-Slavery Sentiment in the Spanish Atlantic World, 17651817. Slavery \& Abolition, 2010, vol. 31, nº 2, p. 181-205.

CAIRNES, J.E. The Slave Power. Londres: Parker, Son, and Bourn, 1862.

CAREY, H.C. The Slave Trade, Domestic and Foreign. Filadelfia: Hart, 1865.

CARLYLE, T. Occasional Discourse on the Negro Question. Fraser's Magazine, 1849, Vol. XL, p. 670-679.

DOMINGO ACEBRÓn, M.D. Rafael María de Labra. Cuba, Puerto Rico, Las Filipinas, Europa y Marruecos, en la España del Sexenio Democrático y la Restauración (18711918). Madrid: CSIC, 2006.

DOMÍNGUEZ, D. Alexander von Humboldt y Ramón de la Sagra: navegación y viaje al interior en la invención de Cuba en el siglo XIX. Hispanic Review, 2015, vol. 83 , $\mathrm{n}^{\mathrm{o}} 2$, p. 143-164.

DU PONT DE NEMOURS, P.S. De l'esclavage des negres. Les Ephémérides du Citoyen, 1771, vol. VI, p. 208-246.

FAWCETT, H. Manual of Political Economy, $5^{\mathrm{a}}$ ed. Londres: Macmillan, 1876[1863].

FERNÁNDEZ CANALES, C. Exposiciones de la opinión pública ante la abolición de la esclavitud en Puerto Rico (1868-1873). Cuadernos de Historia Moderna y Contemporánea, 1987, nº 8, p. 157-171.

FERNÁNDEZ GOLFÍN, L. Breves apuntes sobre las cuestiones más importantes de la Isla de Cuba. Barcelona: El Lloyd Español, 1866.

FERRER DE COUTO, J. Los negros en sus diversos aspectos y condiciones, tales como son, como se suponen que son y cómo deben ser, $2^{\mathrm{a}}$ ed. Nueva York: Imprenta de Hallet, $1864 a$.

FERRER DE COUTO, J. Enough of War!: The Question Of Slavery Conclusively And Satisfactorily Solved, As Regards Humanity At Large And The Permanent Interests Of Present Owners. Nueva York: Imprenta de Hallet, 1864b.

FIGUERA, F. Estudios de Cuba. La Cuestión social. Madrid: Colegio de Sordomudos, 1866.

FOGEL, R.W., y ENGERMAN, S.L. Tiempo en la cruz: la economía esclavista en los Estados Unidos. Madrid: Siglo XXI, 1981.

GALVÁN RODRÍGUEZ, E. La abolición de la esclavituden España. Debates parlamentarios, 1810-1888. Madrid: Dykinson, 2014.

GHORBAL, K. Encuentros y desencuentros con la modernidad antiesclavista: recepción y estrategias de difusión del Tratado de legislación de Charles Comte en Cuba. Dirāsāt Hispānicas, 2014, nº 1, p. 55-75.

GROENEWEGEN, P.D. Thomas Carlyle, 'the Dismal Science', and the contemporary political economy of slavery. History of Economic Review, 2001, n 34, p. 74-94.

GÜELL Y FERRER, J. La rebelión cubana. Barcelona: Imprenta de Narciso Ramírez, 1871.

HERNÁNDEZ, A., y GONZÁLEZ HERRERA, C. El pensamiento abolicionista de Rafael María de Labra, expuesto a través de su actuación parlamentaria. En Esclavitud y Derecho humanos. Madrid: CSIC, 1986, p. 183-204. 
HERNÁNDEZ IGLESIAS, F. La esclavitud y el Señor Ferrer de Couto. Madrid: Imprenta Universal, 1866.

HUMMEL, J.R. Deadweight Loss and the American Civil War: The Political Economy of Slavery, Secession, and Emancipation. [En línea]. Social Science Research Network, 1 de octubre de 2012. <http://dx.doi.org/10.2139/ssrn.2155362>. [7 de febrero de 2016].

LABRA, R.M. de. La abolición de la esclavitud en las Antillas españolas. Madrid: Imprenta J. E. Morete, 1869.

LABRA, R.M. de. La cuestión social en las Antillas Españolas. Madrid: Sociedad Abolicionista Española, 1872.

LABRA, R.M. de. La abolición de la Esclavitud en el orden económico. Madrid: Imprenta de J. Noguera, 1873a.

LABRA, R.M.de. La libertad de los negros de Puerto-Rico, Madrid: Sociedad Abolicionista Española, 1873b.

LABRA, R.M. de. La brutalidad de los negros. Madrid: Imprenta de Aurelio J. Alaria, 1876.

LABRA, R.M. de. D. Fernando de Castro, estudio biográfico. Madrid: El Correo, 1889.

LEVY, D.M. How the dismal science got its name: debating racial quackery. Journal of the History of Economic Thought, 2001, vol. 23, no 1, p. 5-35.

LEVY, D.M., y PEART, S.J. The Secret History of the Dismal Science.Part II. Brotherhood, Trade and the Negro Question. The Library of Economics and Liberty, 200 1, marzo, $\mathrm{n}^{\circ}$ 26. <http://www.econlib.org/library/Columns/LevyPeartdismal2.html>. [20 de septiembre de 2015].

MAAS, H. Olmsted, De Bow, and the weight of evidence on the American slave South. Journal of the History of Economic Thought, 2015, vol. 37, n² 2, p. 171-185.

MALUQUER, J. El problema de la esclavitud y la Revolución de 1868. Hispania, 1971, $\mathrm{n}^{\circ} 117$, p. 55-75.

MANZANEDO, J.M. Memoria que se presenta a los señores socios del Centro HispanoUltramarino de Madrid [ 10 de octubre de 1872]. Madrid: Imprenta Andrés Orejas, 1872a.

MANZANEDO, J.M. Memoria que se presenta a los señores socios del Centro HispanoUltramarino de Madrid [20 de octubre de 1872]. Madrid: Imprenta Andrés Orejas, $1872 b$.

MANZANEDO, J.M. Memoria que se presenta a los señores socios del Centro HispanoUltramarino de Madrid [20 de enero de 1873]. Madrid: Imprenta Andrés Orejas, 1873.

MARX, K. El capital, Libro Primero. Madrid: Siglo XXI, 1975[1867].

MARX, K. The Life-Destroying Toil of Slaves. En PADOVER, S. (ed.). The Karl Marx Library, Vol. II: On America and the Civil War. Nueva York: McGraw-Hill, 1972, p. 21.

MENÉNDEZ ACEBAL, A. La esclavitud y la Economía Política. El Abolicionista, 1875, vol. VI, n 7 , p. 104-105. 
MILL, J.S. The Negro Question. En ROBSON, J. (ed.). The Collected Works of John Stuart Mill, Vol. XXI: Essays on Equality, Law and Education. Toronto: Toronto University Press, 1984[1850], p. 85-96.

MILL, J.S. Principios de economía política. México: FCE, 1985[1848].

MILLER, W.L. J.E. Cairnes on the Economics of American Negro Slavery. Southern Economic Journal, 1964, vol. 30, nº 4, p. 333-341.

NARANJO, C. La amenaza haitiana, un miedo interesado: poder y fomento de la población blanca en Cuba. En GONZÁLEZ-RIPOLL, M.D., NARANJO, C., FERRER, A., GARCÍA, G., y OPTRNÝ J. El rumor de Haití en Cuba: temor, raza y rebeldia. Madrid, CSIC, 2004, p. 83-177.

PASTOR, L.M. Lecciones de Economía Politica. Madrid: Gaceta Economista, 1868.

PERDICES DE BLAS, L., y RAMOS GOROSTIZA, J.L. Blanco White, Spanish America, and Economic Affairs: The Slave Trade and Colonial Trade. History of Political Economy, 2014, vol. 46, n 4, p. 573-608.

PERDICES DE BLAS, L., Y REEDER, J. Diccionario de Historia del Pensamiento Económico (1500-2000). Madrid: Síntesis-Fundación ICO, 2003.

POZUELO, B. Sociedad española y abolicionismo en la segunda mitad del siglo XIX. Cuadernos de Historia Contemporánea, 1988, n 10, p. 71-92.

RODRÍGUEZ, G. La abolición de la esclavitud en los Estados-Unidos. Madrid: Sociedad Abolicionista Española, 1872.

RODRÍGUEZ, G. Los teóricos y los prácticos. El Abolicionista, 1875, vol. VI, nº 1, p. 4-7.

RODRÍGUEZ, G. La idea y el movimiento anti-esclavista en España durante el siglo XIX. En Ateneo Científico, Literario y Artístico de Madrid: La España del siglo XIX, Colección de Conferencias Históricas. Curso de 1886-87, tomo III. Madrid: Librería de Don Antonio San Martín, 1887, p. 321-355.

RODRÍGUEZ, G., LABRA, R.M. de, RUIZ QUEVEDO, M., REGIDOR, M., VIZCARRONDO, J., y CINTRÓN, J.F. La experiencia abolicionista de Puerto-Rico. Exposiciones de la Sociedad Abolicionista Española al Excmo. Sr. Ministro de Ultramar, 15 julio de 1874-30 septiembre de 1874. Madrid: Sociedad Abolicionista Española, 1874.

RODRÍGUEZ BRAUN, C. Un mito perdurable: la economía como ciencia lúgubre. En Economía de los no economistas. Madrid: LID, 2011, p. 35-51.

SACO, J.A. La supresión del tráfico de esclavos africanos en la isla de Cuba; examinada con relación a su agricultura y a su seguridad. En Obras de Don José Antonio Saco, tomo I. Nueva York: Roe Lockwood e hijo, 1853[1845], p. 171-232.

SAGRA, R. de la. Estudios coloniales con aplicación a la isla de Cuba. Vol. I: De los efectos de la supresión del tráfico negrero. Madrid: Imprenta de Dionisio Hidalgo, 1845.

SANROMÁ, J.M. Mis memorias, 2 tomos. Madrid: Tipografía de Manuel G. Hernández, 1887-1894.

SANROMÁ, J.M. La esclavitud en Cuba. Discurso pronunciado en la tercera conferencia abolicionista de 1872. Madrid: Imprenta de T. Fortanet, 1872.

SAY, J.B. Traité d'économie politique, tomo I. París: Crapelet, 1803. 
SAY, J.B. Tratado de economía política, tomo II, traducción de la 5a ed. de 1826. Gerona: Imprenta de V. Oliva, 1839.

SCHMIDT-NOWARA, C. National Economy and Atlantic Slavery: Protectionism and Resistance to Abolitionism in Spain and the Antilles, 1854-1874. Hispanic American Historical Review, 1998, vol. 78, no 4, p. 603-629.

SMITH, A. Investigación sobre la naturaleza y causas de la riqueza de las naciones, 2 vols. Vilassar de Mar: Oikos Tau, 1987[1776].

SMITH, A. Lectures on jurisprudence. Indianapolis: Liberty Fund, 1982.

STEINER, P. Slavery and French Economists, 1750-1830. En DORIGNY, M. (ed.). The Abolitions of Slavery: from L.F. Sonthonax to Victor Schoelcher. Paris: UNESCOBerghahn Books, 2003, p. 133-143.

The Carlyle-Mill "Negro Question" Debate. The History of Economic Thought Website [En línea]. Nueva York: The New School for Social Research, <http://www. newschool.edu/nssr/het/>. [10 de marzo de 2016].

TORRES-CUEVAS, E. La polémica de la esclavitud: José Antonio Saco. La Habana: Editorial de Ciencias Sociales, 1984.

TURGOT, A.R.J. Reflexiones sobre la formación y la distribución de las riquezas. En Cuadro filosófico de los progresos sucesivos del espiritu humano y otros textos. México: FCE, 1998[1766], p. 85-162.

VARELA, F. Memoria que demuestra la necesidad de extinguir la esclavitud en la isla de Cuba. En Obras II. Barcelona: Red Ediciones, 2016[1822], p. 133-140.

VV.AA. Conferencias antiesclavistas del Teatro Lope de Rueda. Madrid: Sociedad Abolicionista Española, 1872.

(c) Copyright: Luis Perdices de Blas y José Luis Ramos Gorostiza, 2017

(c) Copyright: Scripta Nova, 2017.

Ficha bibliográfica:

PERDICES DE BLAS, Luis; RAMOS GOROSTIZA, José Luis. La economía política de la esclavitud: los argumentos económicos del debate abolicionista español del siglo XIX. Scripta Nova. Revista Electrónica de Geografía y Ciencias Sociales. [En línea]. Barcelona: Universitat de Barcelona, 1 de junio de 2017, vol. XXI, nº 567 [ISSN: 1138 9788]. 